\title{
Cinegeo
}

International Journal of Environment and Geoinformatics (IJEGEO) is an international, multidisciplinary, peer reviewed, open access journal.

\section{Ecology of benthic foraminifera of the eastern Aegean Sea coasts}

\author{
Engin MERİÇ., Niyazi AVŞAR., M. Baki YOKEŞ., \\ İpek F. BARUT., Feyza DİNÇER., Cüneyt BİRCAN., Erol KAM
}

\author{
Chief in Editor \\ Prof. Dr. Cem Gazioğlu \\ Co-Editors \\ Prof. Dr. Dursun Zafer Şeker, Prof. Dr. Şinasi Kaya, \\ Prof. Dr. Ayşegül Tanık and Assist. Prof. Dr. Volkan Demir
}

Editorial Committee (April 2020)

\begin{abstract}
Assos. Prof. Dr. Abdullah Aksu (TR), Assit. Prof. Dr. Uğur Algancı (TR), Prof. Dr. Bedri Alpar (TR), Prof. Dr. Lale Balas (TR), Prof. Dr. Levent Bat (TR), Prof. Dr. Paul Bates (UK), İrşad Bayırhan (TR), Prof. Dr. Bülent Bayram (TR), Prof. Dr. Luis M. Botana (ES), Prof. Dr. Nuray Çağlar (TR), Prof. Dr. Sukanta Dash (IN), Dr. Soofia T. Elias (UK), Prof. Dr. A. Evren Erginal (TR), Assoc. Prof. Dr. Cüneyt Erenoğlu (TR), Dr. Dieter Fritsch (DE), Assos. Prof. Dr. Çiğdem Göksel (TR), Prof.Dr. Lena Halounova (CZ), Prof. Dr. Manik Kalubarme (IN), Dr. Hakan Kaya (TR), Assist. Prof. Dr. Serkan Kükrer (TR), Assoc. Prof. Dr. Maged Marghany (MY), Prof. Dr. Michael Meadows (ZA), Prof. Dr. Nebiye Musaoğlu (TR), Prof. Dr. Erhan Mutlu (TR), Prof. Dr. Masafumi Nakagawa (JP), Prof. Dr. Hasan Özdemir (TR), Prof. Dr. Chryssy Potsiou (GR), Prof. Dr. Erol Sarı (TR), Prof. Dr. Maria Paradiso (IT), Prof. Dr. Petros Patias (GR), Prof. Dr. Elif Sertel (TR), Prof. Dr. Nüket Sivri (TR), Prof. Dr. Füsun Balık Şanlı (TR), Prof. Dr. Uğur Şanlı (TR), Duygu Ülker (TR), Assoc. Prof. Dr. Oral Yağcı (TR), Prof. Dr. Seyfettin Taş (TR), Assoc. Prof. Dr. Ömer Suat Taşkın (US), Dr. İnese Varna (LV), Dr. Petra Visser (NL), Prof. Dr. Selma Ünlü (TR), Assoc. Prof. Dr. İ. Noyan Yilmaz (AU), Prof. Dr. Murat Yakar (TR), Assit. Prof. Dr. Sibel Zeki (TR)
\end{abstract}

Abstracting and Indexing: TR DIZIN, DOAJ, Index Copernicus, OAJI, Scientific Indexing Services, International Scientific Indexing, Journal Factor, Google Scholar, Ulrich's Periodicals Directory, WorldCat, DRJI, ResearchBib, SOBIAD 


\title{
Ecology of benthic foraminifera of the eastern Aegean Sea coasts
}

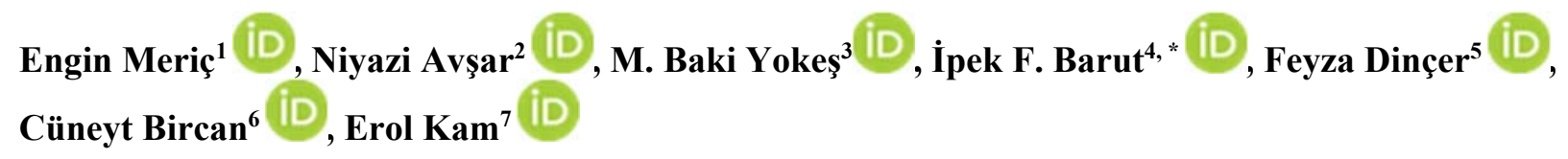

${ }^{1}$ Moda Hüseyin Bey S. No: 15/4 34710 KADIKOY, ISTANBUL-TR

${ }^{2}$ Cukurova University, Faculty of Engineering and Architect., Dept. of Geological Engineering, 01330 BALCALI, ADANA-TR

${ }^{3}$ Hanımefendi Sokak No: 160/9, 34384 ŞIŞLL், ISTANBUL-TR

${ }^{4}$ Istanbul University, Institute of Marine Sciences and Management, 34134 VEFA, ISTANBUL-TR

${ }^{5}$ Nevşehir University, Faculty of Engineering and Architect., Dept. of Geological Engineering, 50300 NEVSEHIR-TR

${ }^{6}$ Balıkesir University, Faculty of Engineering and Architect., Dept. of Geological Engineering, 10165 BALIKESIR-TR

${ }^{7}$ Y 1 ldiz Technical University, Faculty of Science and Letters, Dept. of Physics, 34220 ESENLER, ISTANBUL-TR

* Corresponding author

Received 07 Nov 2019

E-mail : barutif@istanbul.edu.tr

Accepted 25 March 2020

How to cite: Meriç et al., (2020). Ecology of benthic foraminifera of the eastern Aegean Sea coasts, International Journal of Environment and Geoinformatics (IJEGEO), 7(1): 06-22. DOI: 10.30897/ijegeo.627856

\begin{abstract}
The aim of this study was to determine the distribution of benthic foraminifera in some field of the Turkish Aegean coasts have been investigated and the effects of ecological changes observed on these fauna in 2009-2014 period. Sediment samples from Alibey and Maden Islands (Balıkesir), Kuşadası (Aydın), Çeşme Ilıca Bay (Izmir) and northwestern coast of Karaburun Peninsula (Izmir) have been analysed. Similarities, as well as dissimilarities were observed between the assemblages from different locations. The Red Sea orginated alien foraminifer Amphistegina lobifera Larsen was found to form a very dense population around the south and west part of a submarine spring water in Kuşadası, where as it was replaced by Ammonia compacta Cushman and Elphidium crispum (Linné) assemblages on the northern and eastern parts. Euthymonacha polita (Chapman) has been first recorded in Kuşadas1 and it is also abundant in the Ilica Bay. The Red Sea originated Coscinospira acicularis (Batsch) has also been first recorded in the Mediterranean from Ilica Bay. Presence of the individuals with colored tests indicates the presence of heavy metals in spring waters. Aberrant aperture morphologies observed in some of the Vertebralina striata d'Orbigny individuals attracts attention. Therefore, abundance of individuals with colored tests, morphological deformities or togetherness, as well as the Red Sea originated species have indicated the special environmental and ecological conditions around the submarine springs. The main reasons for these ecological changes are salinity changes, the presence of heavy metals, thermal springs and cold-water springs. It is noteworthy that there is a different benthic foraminiferal living due to physical and chemical changes in the regions where different ecological conditions develop around the submarine thermal / cold water springs observed in these coastal regions.
\end{abstract}

Keywords: Alibey and Maden Islands (Ayvalık, W-TR coasts), Benthic Foraminifer, Ecological Factors, Ilıca Bay, Karaburun Peninsula, Gulf of Kuşadası.

\section{Introduction}

Morphological differences have been observed in the tests of benthic foraminifers from recent sediment samples collected at different locations and depths on the Turkish Aegean and Levantine coast (Meriç et al., 2002, 2003b, 2009b). Alterations in the ecological conditions have been found to be the main reason causing these kinds of morphological abnormalities. Besides the studies performed by researchers from various countries, in our previous studies also we have shown that extreme salinity, rapid changes in salinity, presence of heavy metals and trace elements, both thermal and cold water submarine springs and the chemical compositions of the submarine spring waters in karstic regions are suggested to be the main factors which cause changes ecological conditions (Nigam et al., 2006; Meriç et al., 2003a, b, 2009a, b, c, 2010, 2012a, b;Okuş et al., 2004,2006, 2010; Yokeş et al., 2014; Simav, et al., 2015 Meriç et al., 2016; Demir et al., 2016; Gazioğlu, 2018; Duman et al., 2019).
Our recent studies conducted on the eastern Aegean Sea coasts of revealed similarities and dissimilarities in the foraminiferal assemblages from located around Alibey and Maden islands, Çeşme Ilıca Bay (Izmir), northwestern coast of Karaburun Peninsula and Gulf of Kuşadası (Figure $1 \mathrm{a}-\mathrm{d}$ ). The Aegean Sea coast of Turkey, both in the sea and near-shore areas include hot and coldwater outlets (Çağlar, 1946; Başkan \& Canik, 1983). In addition, a large number of mineral deposits are known to exist in the region. Therefore, mineral deposits in the underground or the mineral concentration of ground water was carried to the sea by various rivers to the benthic foraminifera and trace elements survived an impact on coastal areas provide a well-known fact (Yalçın et al., 2008; Meriç et al., 2009b). Numerous hot water springs are found around Gulf of Kuşadası.

The thermal mineral waters have a temperature range of 19-64 oC (Figure 1d) (Yenal et al., 1974; Barut et al., 2004). In Doganbey Cape (Seferihisar), there are terrestrial as well as submarine springs, of which the 
temperatures range between $66-70 \mathrm{oC}$. The variations observed in the concentrations of the elements are noteworthy. The concentration of $\mathrm{Br}$ is much above the average values reported for earth's crust $(2.5 \mathrm{mg} / \mathrm{l})$, sandstone $(1 \mathrm{mg} / \mathrm{l})$ and limestone $(6.2 \mathrm{mg} / \mathrm{l})$ (Turekian \& Wedepohl, 1961; Mason \& Moore, 1982). Even though trace level of heavy metals that have been disposed into the natural environment due to human activities, in time they accumulate in soil, water, sediments as well as in plants and animals. Inspired by a study done in the western part of Greenland (Elberling et al., 2003) a similar research was carried out in the present study basing upon the samples of the cores cut at the seafloor stations located around Alibey and Maden islands (Figure 1a) (Meriç et al., 2009c, 2017).
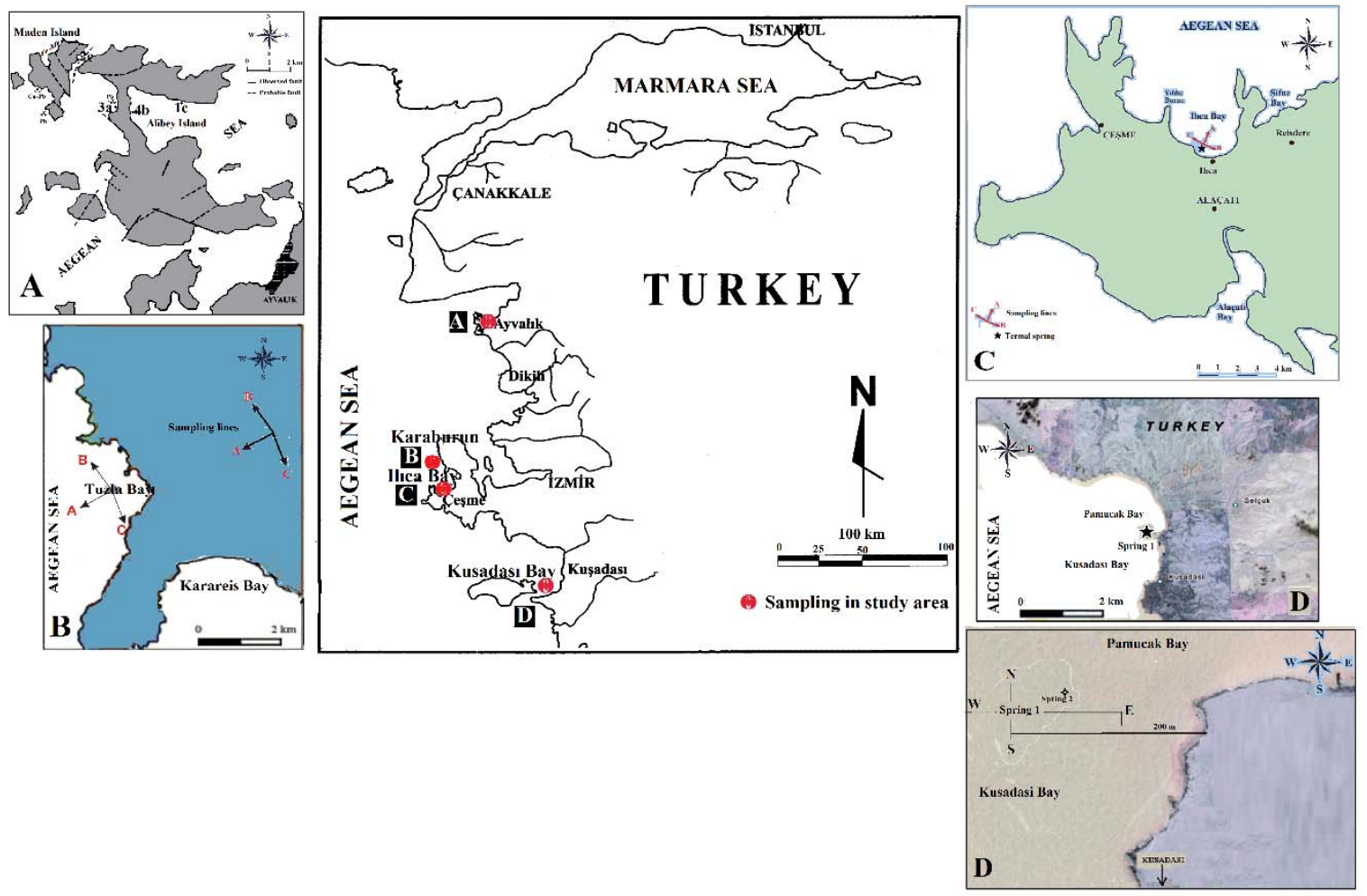

Fig. 1. Location map of study areas.

Those islands are located along southern cost of the Gulf of Edremit which is NE extension of Aegean Sea. Part of the recent sediments deposited in study area is red-brown in color. Coloured tests and morphological disorders related to Peneroplis are interesting occurrences to notify. The test views of foraminifera also include various abnormal individuals in the second locality Karaburun Peninsula (Figure 1b) (Meriç et al., 2012b). Transported of heavy metals and trace elements to marine environment in the northern part of the Karaburun Peninsula (Figure 1b) were related to Karareis mercury mine bedrock and numerous fault systems, NE-SW partly, NW-SE, N-S (Çakmakoğlu \& Bilgin, 2006). A rich foraminifer assemblages were observed around a submarine spring located $200 \mathrm{~m}$ of the shore in Pamucak Bay (Kuşadas1, Aydin) (Figure 1d), at a depth of $12.40 \mathrm{~m}$. The temperature of the springs was 19.6 oC (Yokeş et al., 2014). The Red Sea species, Amphistegina lobifera Larsen was found to be the dominant species on the southern and western part of the spring.

Another such thermal water as submarine spring water which is located at a depth of $2.50 \mathrm{~m}$ on Yildiz Cape, Ilıca Bay (Çeşme-Izmir) (Figure 1c) was investigated for its recent benthic foraminifera assemblages. The thirty-eight surface sediment samples have been collected on 3 transects.
The Pacific Ocean and the Red Sea originated benthic foraminifera were abundantly observed (Meriç et al., 2012a).

The distribution pattern of the species, site specific abundance of Indo-Pacific originated ones, the presence of morphological abnormalities in test structure together with color formation were found to be noteworthy (Meriç et al., 2010, 2011, 2012a, b). Known that like it is observed on the land, the submarine springs and spas found on the Aegean coasts create special ecological conditions which cause the formation of benthic foraminifer assemblages different than observed in other locations. Different living conditions were occurred around thermal spas in submarine spring waters in according structure fault lines (Meriç et al., 2003a, b, 2012a; Yalçın et al., 2008).

The aim of this study was to evaluate by the effects of physical, chemical and radioactive properties of the environmental conditions on the foraminiferal assemblages, by means of abnormal individuals with colored tests and/or morphological deformity, abundance pattern, indivuals with abnormal togetherness and aliens species around Alibey and Maden islands (Ayvalık), NE and SW Karaburun Peninsula, Ilıca Bay and Gulf of Kuşadası. 


\section{Material and Methods}

Sediment samples were manually collected by a plastic shovel during SCUBA diving in locations of Karaburun Peninsula (İzmir), Ilıca ( Çeşme) and Gulf of Kuşadası, and at distances of 5, 10, 15, 20, 25, 30, 35, 40, 45, 50, 60, $70,80,90$ and $100 \mathrm{~m}$ in lines. Of total 90 samples taken on 07.11.2008, 45 were taken from the SW part of Karaburun Peninsula (Karaburun-I) on lines A $\left(210^{\circ}\right)$, B $\left(125^{\circ}\right)$ and $\mathrm{C}\left(290^{\circ}\right)$, and 45 further samples were taken (Figure 1b, Table 1).

Thirty-eight sediment samples were collected around the submarine spring water in the Ilica Bay in November 2008 (Figure 1c, Table 1). Taking the center of this spring as the starting point (coordinates: $0444185 \mathrm{E}$ and 4240949 $\mathrm{N})$ three transect lines were determined with different angles set (Line A $210^{\circ}$, Line B $120^{\circ}$ and Line C $292^{\circ}$ ). In the first $50 \mathrm{~m}$ from the spring, sediment samples were collected at each $5 \mathrm{~m}$ distance and at each $10 \mathrm{~m}$ distance between 50-100 m. But because of a jetty, samples could not be obtained on line A after $40 \mathrm{~m}$ of distance. The spring temperature was measured as $28.4^{\circ} \mathrm{C}$. A total of eleven cores were taken at four stations located north of the Alibey Island (3 sites) and east of the Maden Island (Figure 1a, Table 1). The cores were split longitudinally into two halves. One-half of each core was used for microfaunal investigation. The foraminifera samples were taken every $2 \mathrm{~cm}$. Two $\mathrm{cm}$ sampling interval is applied for benthic foraminifer investigations.

For paleontological analyses in all sampling five grams of wet sediment samples were weighed and $10 \%$ hydrogen peroxide (H2O2) was added for 24 hours. Then these samples were washed by pressurized water in a $0.063 \mathrm{~mm}$ mesh size sieve. Remaining coarser residues in the sieve were dried in an oven at $50^{\circ} \mathrm{C}$ temperature. The dried samples were progressively sieved through $2.00,1.00$, 0.500, 0.250, $0.125 \mathrm{~mm}$ mesh sizes (Babin, 1980; Bignot, $1985)$ and then examined under binocular microscope in order to determine characteristics of the fauna. Almost all the samples contained Amphistegina lobifera Larsen individuals $0.50 \mathrm{~mm}-1.00 \mathrm{~mm}$ in size. Although a rich foraminifer fauna was observed over the $0.25 \mathrm{~mm}$ and $0.125 \mathrm{~mm}$ mesh sized sieve, Amphistegina lobifera Larsen individuals were very scarce.

For laboratory analyses of the samples that in Alibey and Maden islands, in Karaburun Peninsula and in Ilica Bay ( Çeşme) were performed elemental chemical analysis conducted in CNAEM (Cekmece Nuclear Research and Training Center) by Wavelength Dispersive X-ray Fluorescence (WDXRF) Spectrophotometry. Recordings of the solid, liquid and gas samples were obtained at ppm level and bbp level was reached when pre-enrichment was done. Quantitative and qualitative analysis of the elements between Boron (B) and Uranium (U) were performed using X0 ray tube, various crystals (LiF220, PX10, GeIIIC, PE 202-C), two receptors, collimators with various sizes and characteristics and by a computer program. Before analysis, samples were ground to 200 mesh size and dried in desiccator. $12 \mathrm{~g}$ of dried sample was mixed with $3 \mathrm{~g}$ of wax, placed in $40 \mathrm{~mm}$ mold and pelleted under 35 ton of pressure. Electron microprobe quantitative analysis was performed by computer controlled JEOL733 electron microprobe instrument and online ZAFM quantitative analysis program.

In the Gulf of Kuşadası of spring water was measured at it was center and four vertical lines were set on south, north, east and west directions (Figure 1d, Table 1). A total of 45 sediment samples were collected at around the submarine spring water from different points on the lines in Kuşadasi-Pamucak Bay (Figure 1d, Table 1). The spring water was located $200 \mathrm{~m}$ of the coast at $12.4 \mathrm{~m}$ depth and its temperature was $19.6^{\circ} \mathrm{C}$. Temperature and depth of the seawater were manually measured on the Gulf of Kuşadası samples. Seawater samples taken for the quality and quantity of phytoplankton cells were transferred to $1000 \mathrm{ml}$ capacity PVC containers and fixed with borax buffered formaldehyde $(10 \mathrm{ml} / \mathrm{l})$ and transferred to Istanbul University Institute of Marine Sciences and Management, Biology Laboratory in 24 hours. The Hg values were measured in Shimadzu 6701 AAS Hydride Unit in Istanbul University Institute of Marine Sciences and Management, Marine Chemistry Laboratory.

For heavy metal and trace element (Al, Si, Ti, Cr, Mn, Fe, $\mathrm{Co}, \mathrm{Ni}, \mathrm{Cu}, \mathrm{Zn}, \mathrm{As}, \mathrm{Cd}, \mathrm{Hg}$ ve $\mathrm{Pb}$ ) analysis water sample was collected in 0.51 polyethylene bottle containing $2 \mathrm{ml}$ $\mathrm{HCl}$. The analyses were done in Çukurova University, Faculty of Engineering and Architecture, Department of Geology, Geochemistry Laboratory. Since the sample was liquid, it is directly used for the analysis with Atomic Absorbsion Spectrophotometer 700. For As and $\mathrm{Hg}$ readings, the elements were reduced with sodium borohydride before measurement. $\mathrm{Hg}$ readings were measured in Shimatzu 6701 AAS Hidride Unit in Istanbul University Institute of Marine Sciences and Management, Marine Chemistry Laboratory. The spring water was frozen without adding any preservatives and sent to TÜBİTAK MAM Institute of Chemistry and Environment laboratory as quick as possible for nutrient analysis. N, P, $\mathrm{Si}, \mathrm{NH} 3$, total nitrogen and total phosphate analysis were measured by autoanalyser.

\section{Results}

\section{Benthic Foraminifer Assemblages}

The foraminifer assemblage found around Maden and Alibey islands (Ayvalık) is composed of 29 genera and 52 species (systematics after Loeblich \& Tappan, 1988) (Appendix 1). Foraminiferal assemblages observed in the study area is not rich as the assemblages that have been encountered in the other studied areas in eastern Aegean coastline. 
Table 1. Line, distance, depth and water temperature measurements and the distribution of Amphistegina lobifera Larsen individuals among sediment samples from Kuşadası.

\begin{tabular}{|c|c|c|c|c|c|c|}
\hline & Line & Horizontal distance & Side & Depth (m) & Water temperature $\left({ }^{\circ} \mathrm{C}\right)$ & Number of Amphistegina lobifera \\
\hline \multirow{45}{*}{ 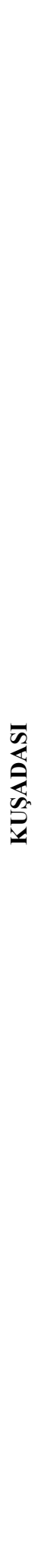 } & A & From spring & From spring & 12.4 & 19.6 & 305 \\
\hline & A & $5 \mathrm{~m}$ & South & 11.1 & 17.5 & 262 \\
\hline & A & $10 \mathrm{~m}$ & South & 9.7 & 17.5 & 627 \\
\hline & A & $15 \mathrm{~m}$ & South & 9.2 & 17.5 & 753 \\
\hline & A & $20 \mathrm{~m}$ & South & 9.5 & 17.5 & 866 \\
\hline & A & $25 \mathrm{~m}$ & South & 10.5 & 17.5 & 1072 \\
\hline & $\mathrm{A}$ & $30 \mathrm{~m}$ & South & 11.3 & 17.5 & 368 \\
\hline & A & $35 \mathrm{~m}$ & South & 12.3 & 17.5 & 154 \\
\hline & A & $40 \mathrm{~m}$ & South & 12.5 & 17.5 & 116 \\
\hline & A & $45 \mathrm{~m}$ & South & 13.7 & 17.5 & 185 \\
\hline & A & $50 \mathrm{~m}$ & South & 14.9 & 17.5 & 93 \\
\hline & $\mathrm{B}$ & $5 \mathrm{~m}$ & North & 8.9 & 17.5 & 76 \\
\hline & $\mathrm{B}$ & $10 \mathrm{~m}$ & North & 8.5 & 17.5 & 71 \\
\hline & B & $15 \mathrm{~m}$ & North & 8.7 & 17.5 & 30 \\
\hline & B & $20 \mathrm{~m}$ & North & 9.0 & 17.5 & 41 \\
\hline & B & $25 \mathrm{~m}$ & North & 10.1 & 17.5 & 16 \\
\hline & B & $30 \mathrm{~m}$ & North & 10.9 & 17.5 & 18 \\
\hline & B & $35 \mathrm{~m}$ & North & 12 & 17.5 & 34 \\
\hline & B & $40 \mathrm{~m}$ & North & 13.1 & 17.5 & 20 \\
\hline & B & $45 \mathrm{~m}$ & North & 14.2 & 17.5 & 9 \\
\hline & B & $50 \mathrm{~m}$ & North & 20.1 & 17.5 & 5 \\
\hline & $\mathrm{C}$ & $5 \mathrm{~m}$ & West & 9.1 & 17.5 & 1954 \\
\hline & $\mathrm{C}$ & $10 \mathrm{~m}$ & West & 9.3 & 17.5 & 303 \\
\hline & $\mathrm{C}$ & $15 \mathrm{~m}$ & West & 11.3 & 17.5 & 639 \\
\hline & $\mathrm{C}$ & $20 \mathrm{~m}$ & West & 12.8 & 17.5 & 374 \\
\hline & $\mathrm{C}$ & $25 \mathrm{~m}$ & West & 14.7 & 17.5 & 242 \\
\hline & $\mathrm{C}$ & $30 \mathrm{~m}$ & West & 17.3 & 17.5 & 72 \\
\hline & $\mathrm{C}$ & $35 \mathrm{~m}$ & West & 17.9 & 17.5 & 55 \\
\hline & $\mathrm{C}$ & $40 \mathrm{~m}$ & West & 18.2 & 17.5 & 65 \\
\hline & $\mathrm{C}$ & $45 \mathrm{~m}$ & West & 22.3 & 17.5 & 12 \\
\hline & D & $5 \mathrm{~m}$ & East & 12.8 & 17.5 & 153 \\
\hline & D & $10 \mathrm{~m}$ & East & 11.9 & 17.5 & 44 \\
\hline & $\mathrm{D}$ & $15 \mathrm{~m}$ & East & 12.1 & 17.5 & 149 \\
\hline & D & $20 \mathrm{~m}$ & East & 11.5 & 17.5 & 161 \\
\hline & $\mathrm{D}$ & $25 \mathrm{~m}$ & East & 14.4 & 17.5 & 121 \\
\hline & $\mathrm{D}$ & $30 \mathrm{~m}$ & East & 15.3 & 17.5 & 77 \\
\hline & $\mathrm{D}$ & $35 \mathrm{~m}$ & East & 15.9 & 17.5 & 127 \\
\hline & $\mathrm{D}$ & $40 \mathrm{~m}$ & East & 18.1 & 17.5 & 109 \\
\hline & $\mathrm{D}$ & $45 \mathrm{~m}$ & East & 19.1 & 17.5 & 8 \\
\hline & $\mathrm{D}$ & $50 \mathrm{~m}$ & East & 19.5 & 17.5 & 1 \\
\hline & $\mathrm{D}$ & $60 \mathrm{~m}$ & East & 19.4 & 17.5 & 2 \\
\hline & $\mathrm{D}$ & $70 \mathrm{~m}$ & East & 19.1 & 17.5 & 1 \\
\hline & $\mathrm{D}$ & $80 \mathrm{~m}$ & East & 20.2 & 17.5 & 0 \\
\hline & $\mathrm{D}$ & $90 \mathrm{~m}$ & East & 20.1 & 17.5 & 0 \\
\hline & $\mathrm{D}$ & $100 \mathrm{~m}$ & East & 20.2 & 17.5 & 3 \\
\hline
\end{tabular}


Table 2. Line, distance, depth and water temperature measurements and the distribution of Amphistegina lobifera Larsen individuals among sediment samples from Karaburun-I, Ayvalık and Çeşme-Ilıca.

\begin{tabular}{|c|c|c|c|c|c|c|}
\hline 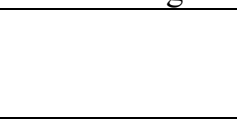 & Line & $\begin{array}{c}\text { Horizontal } \\
\text { distance }\end{array}$ & Side & $\begin{array}{l}\text { Depth } \\
\text { (m) }\end{array}$ & $\begin{array}{c}\text { Water } \\
\text { temperature } \\
\left({ }^{\circ} \mathrm{C}\right) \\
\end{array}$ & $\begin{array}{c}\text { Number of } \\
\text { Amphistegina } \\
\text { lobifera } \\
\end{array}$ \\
\hline \multirow{45}{*}{ 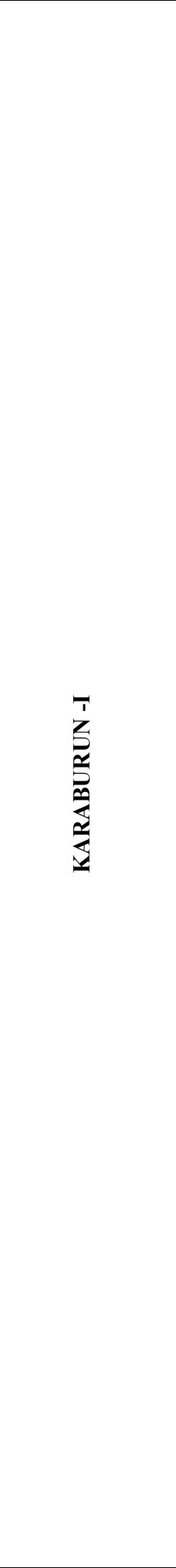 } & A & 5 & Southwest & 1 & 17.8 & 6 \\
\hline & A & 10 & Southwest & 1.1 & 17.6 & 6 \\
\hline & A & 15 & Southwest & 1.8 & 17.6 & 7 \\
\hline & A & 20 & Southwest & 2.5 & 17.6 & 15 \\
\hline & A & 25 & Southwest & 3.2 & 17.2 & 16 \\
\hline & A & 30 & Southwest & 3.8 & 17.2 & 12 \\
\hline & A & 35 & Southwest & 4.9 & 17 & 88 \\
\hline & A & 40 & Southwest & 6.6 & 17 & 69 \\
\hline & A & 45 & Southwest & 7.6 & 16.8 & 76 \\
\hline & A & 50 & Southwest & 9.1 & 16.8 & 61 \\
\hline & A & 60 & Southwest & 11.8 & 16.8 & 92 \\
\hline & A & 70 & Southwest & 13.9 & 16.8 & 27 \\
\hline & A & 80 & Southwest & 15.3 & 16.7 & 19 \\
\hline & A & 90 & Southwest & 17.5 & 16.7 & 4 \\
\hline & A & 100 & Southwest & 19.3 & 16.7 & 1 \\
\hline & B & 5 & Northwest & 1 & 17.6 & 1 \\
\hline & B & 10 & Northwest & 1 & 17.6 & 0 \\
\hline & B & 15 & Northwest & 1 & 17.6 & 5 \\
\hline & B & 20 & Northwest & 1 & 17.6 & 8 \\
\hline & B & 25 & Northwest & 1 & 17.4 & 1 \\
\hline & B & 30 & Northwest & 1.2 & 17.2 & 1 \\
\hline & B & 35 & Northwest & 1.2 & 17.2 & 4 \\
\hline & B & 40 & Northwest & 1.2 & 17.2 & 2 \\
\hline & B & 45 & Northwest & 1.4 & 17 & 4 \\
\hline & B & 50 & Northwest & 1.4 & 17 & 0 \\
\hline & B & 60 & Northwest & 1.6 & 17 & 3 \\
\hline & B & 70 & Northwest & 2 & 17 & 2 \\
\hline & B & 80 & Northwest & 1.9 & 17 & 1 \\
\hline & $\mathrm{B}$ & 90 & Northwest & 2.3 & 17 & 0 \\
\hline & $\mathrm{B}$ & 100 & Northwest & 2.4 & 17 & 0 \\
\hline & $\mathrm{C}$ & 5 & Southeast & 1.2 & 17.2 & 3 \\
\hline & $\mathrm{C}$ & 10 & Southeast & 1.4 & 17.1 & 3 \\
\hline & $\mathrm{C}$ & 15 & Southeast & 1.7 & 17.1 & 3 \\
\hline & $\mathrm{C}$ & 20 & Southeast & 2 & 17.1 & 15 \\
\hline & $\mathrm{C}$ & 25 & Southeast & 2.3 & 16.9 & 7 \\
\hline & $\mathrm{C}$ & 30 & Southeast & 2.3 & 16.9 & 11 \\
\hline & $\mathrm{C}$ & 35 & Southeast & 2.4 & 16.9 & 32 \\
\hline & $\mathrm{C}$ & 40 & Southeast & 2.5 & 16.9 & 30 \\
\hline & $\mathrm{C}$ & 45 & Southeast & 2.7 & 16.9 & 25 \\
\hline & $\mathrm{C}$ & 50 & Southeast & 3.1 & 16.9 & 7 \\
\hline & $\mathrm{C}$ & 60 & Southeast & 3.4 & 16.9 & 6 \\
\hline & $\mathrm{C}$ & 70 & Southeast & 3.5 & 16.9 & 26 \\
\hline & $\mathrm{C}$ & 80 & Southeast & 3.1 & 16.9 & 5 \\
\hline & $\mathrm{C}$ & 90 & Southeast & 2.9 & 16.9 & 8 \\
\hline & $\mathrm{C}$ & 100 & Southeast & 2.7 & 16.9 & 4 \\
\hline AYVALIK & Core $1 \mathrm{c}$ & & & $1.66-1.68$ & & 1 \\
\hline ÇEŞME-ILICA & & & & & & 0 \\
\hline
\end{tabular}




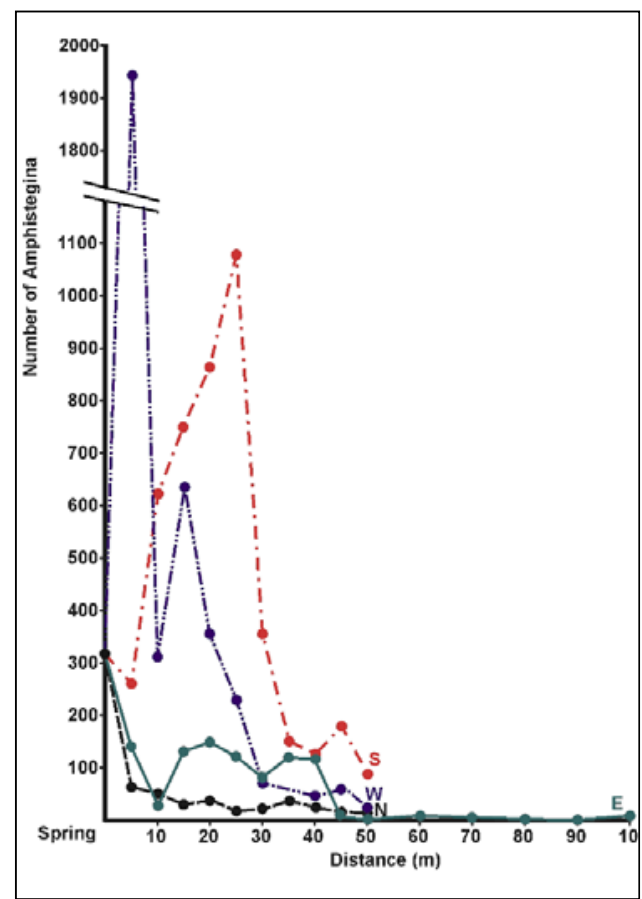

Fig. 2. The quantitative distribution pattern of Amphistegine lobifera Larsen sampled by east, west, north, and south directions from around the Pamucak Bay (Kuşadası) submarine water spring.

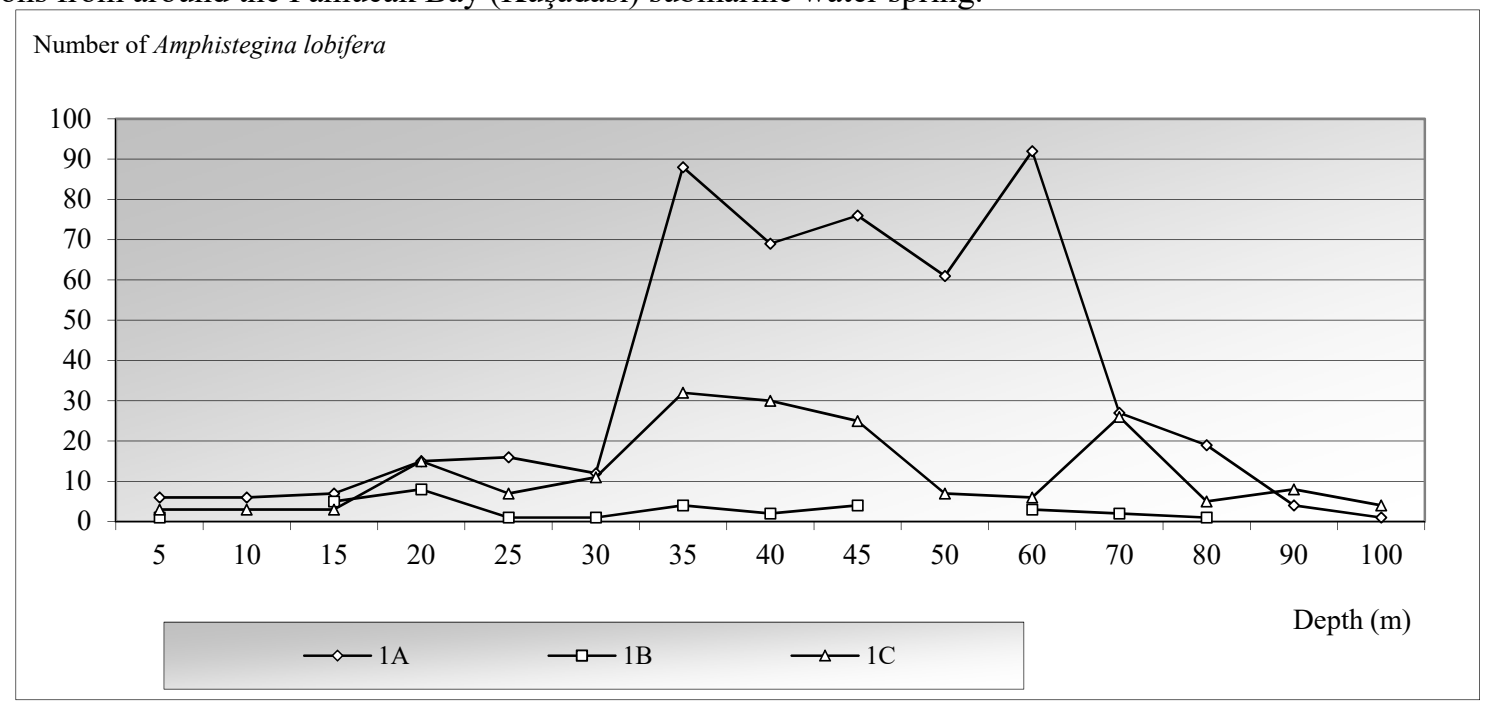

Fig. 3. The quantitative distribution pattern of Amphistegine lobifera Larsen sampled by directions from around the Karaburun A, B, C lines. (from Meric et al., 2012b).

In forty-five samples collected from SW of Karaburun Peninsula 48 genera and 84 species were observed (Appendix 2). The thirty-eight samples collected around the submarine spring water in Çeşme-Ilıca Bay were found to contain 45 genera and 80 species of foraminifera (Appendix 3), including 10 genera and 10 species of IndoPacific origin; (Nodopthalmidium antillarum (Cushman), Spiroloculina antillarum d'Orbigny, Triloculina fichteliana d'Orbigny, Euthymonacha polita (Chapman), Coscinospira acicularis (Batsch), Monalysium acicularis (Batsch), Peneroplis arietinus (Batsch), Amphisorus hemprichii Ehrenberg, Cymbaloporetta plana (Cushman), Amphistegina lobifera Larsen) (Table 2, Plates 1-4; linear scale: 100 micron). A rich foraminiferal fauna was observed in Gulf of Kuşadası (Appendix 4) and analyzed of 45 sediment samples revealed the presence of 59 genera and 103 species.

Evaluation of Alien Species, Abnormal Species with Colored Tests or Morphological Deformities or Togetherness in the Study Areas

The foraminifer assemblages showing abnormal features, such as colored tests, morphological deformities or togetherness, in Ayvalık-Alibey Maden islands which was identified beside the normal benthic foraminifer assemblage in cores (Figure 1a, 1c, 2c and 3a) is composed predominantly of Lobatula lobatula (Walker and Jacob), Ammonia compacta Hofker, A. parkinsoniana (d'Orbigny), Challengerella bradyi Billman, Hottinger and Oesterle, Elphidium complanatum (d'Orbigny), E 
crispum (Linné); and while in core $4 \mathrm{~b}$ Peneroplis pertusus (Forskal) and P. planatus (Fichtel and Moll) were the abundantly observed abnormal individuals. Additionally, a few speciemens of Spiroloculina angulata (d'Orbigny),
Cibicidella variabilis (d'Orbigny) were found to display features similar to the abovementioned ones. A single individual of Amphistegina lobifera Larsen has been only observed in core ( $1 \mathrm{c}$ ) (Table 2).

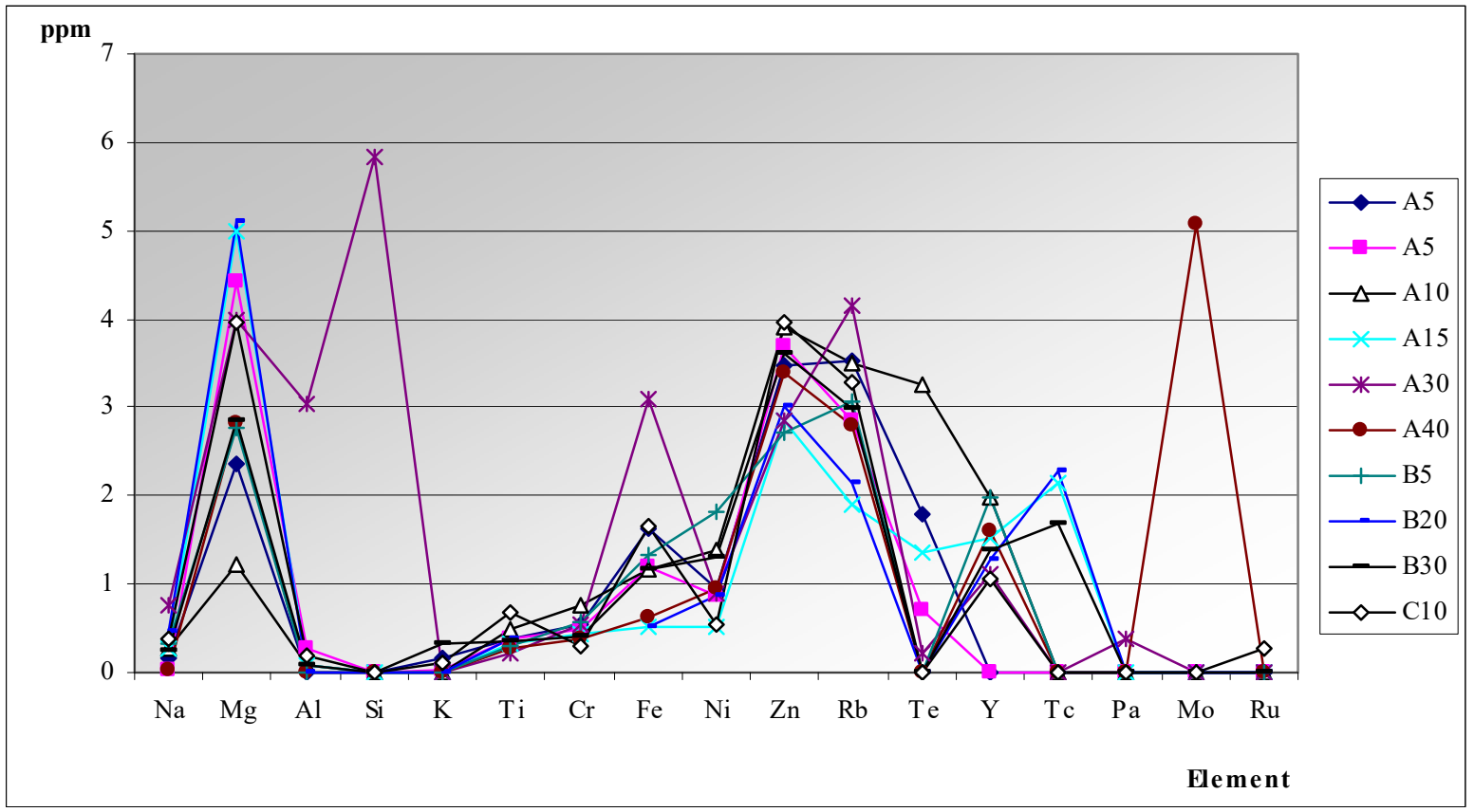

Fig. 4. Distribution of chemical analyses in coloured tests of Peneroplis planatus (Fichtel and Moll) in Ilıca Bay.

ppm

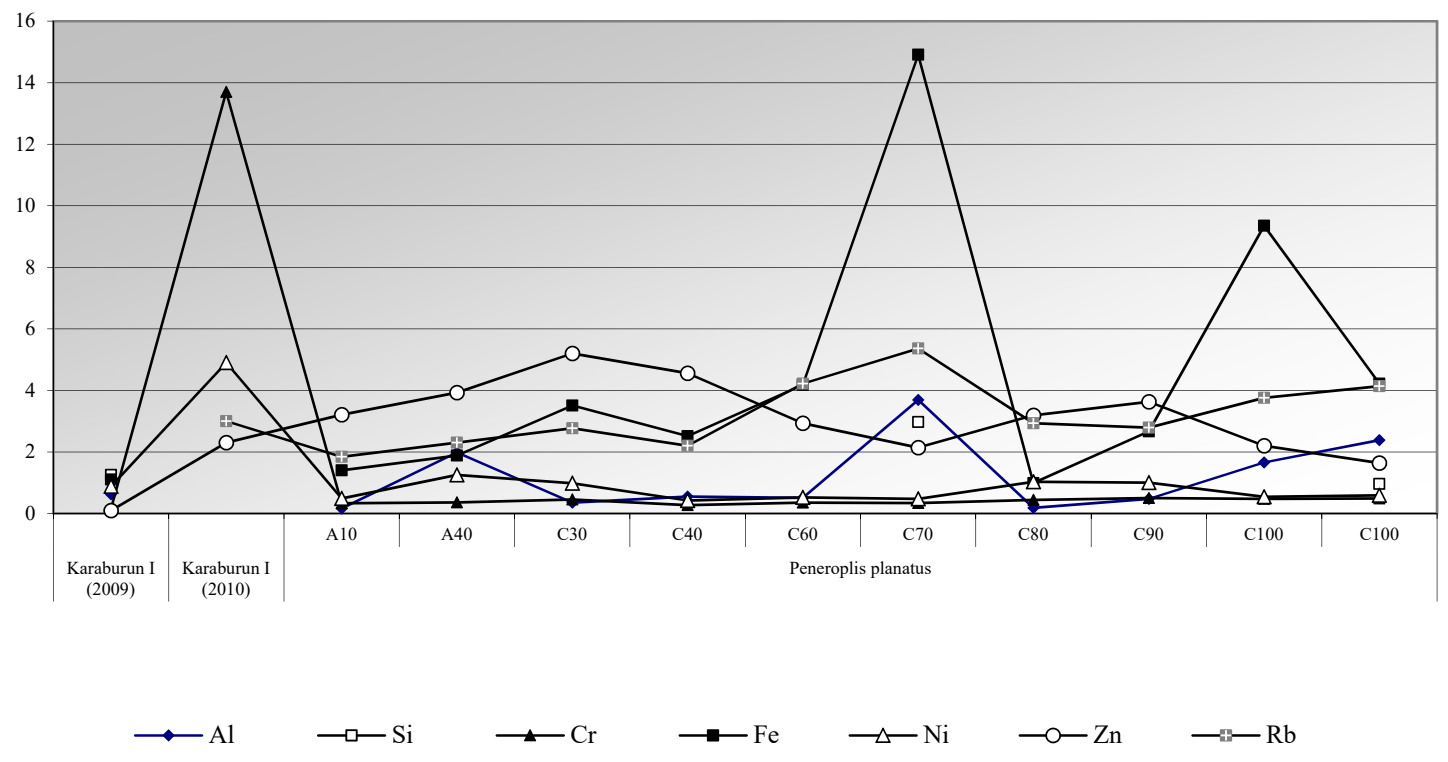

Figure 5. Distribution of heavy metal and trace elements in coloured tests of Peneroplis planatus in some samples and seawater in Karaburun.

Ilıca Bay (Çeşme-Izmir) was investigated for recent benthic foraminifer assemblage. The thirty-eight surface sediment samples have been collected on 3 transects. The Pacific Ocean and the Red Sea originated benthic foraminifera were abundantly observed. However Amphistegina lobifera Larsen specimens did not observed (Table 2). The identified species were Nodopthalmidium antillarum (Cushman), Spiroloculina antillarum d'Orbigny, Triloculina cf. fichteliana d'Orbigny, Euthymonacha polita (Chapman), Coscinospira acicularis (Batsch), Peneroplis arietinus (Batsch), Amphisorus hemprichii Ehrenberg, Sorites orbiculus Ehrenberg, Cymbaloporetta plana (Cushman). Beside these species, Peneroplis arietinus (Batsch), Spiroloculina antillarum d'Orbigny, Triloculina cf. fichteliana d'Orbigny and Cymbaloporetta plana (Cushman) which were recorded on the SW coasts of Antalya were also found in this region. Euthymonacha polita (Chapman) which was first recorded (Meriç et al., 2010) in Gulf of Kuşadası is also abundant in Ilıca Bay. 
This observation shows a northward spread of this species. Coscinospira acicularis (Batsch) is a SW Pacific originated species which is also found in Gulf of Aqaba, north of Red Sea. It is a typical immigrant species inhabiting the Ilica Bay. This is the first record of this species both for the Mediteeranean and for Aegean Sea.

Major differences in foraminiferal assemblages have been observed between the eastern and western coasts on the northern part of the Karaburun Peninsula. In contrast to the rich fauna of the western coast (Table 2), a poor assemblage was found on the eastern coast, which is located in the Gulf of İzmir. A great difference in population sizes have also been observed in Amphistegina lobifera Larsen assemblages found on the Aegean coasts of Karaburun Peninsula and Gulf of İzmir. These individuals were in core 1a in range of 30-70 m (Figure 3 ). In the frame work of this study, 67 foraminifer species were identified. The most abundant species were Ammonia tepida Cushman, Elphidium crispum (Linné), Ampicoryna scalaris (Batsch), Nonionella turgida (Williamson) and Nonion depressulum (Walker and Jacob). Highest heavy metal pollution was observed in the inner part of the Gulf, where least number of foraminifera species observed.

It was found that all the samples in Gulf of Kuşadas1 included Amphistegina lobifera Larsen specimens with
0.50-1.00 $\mathrm{mm}$ sizes. A considerable amount of foraminifer specimens was observed over the 0.250 and $0.125 \mathrm{~mm}$ sieves, however the amount of Amphistegina lobifera Larsen individuals was very low. Abnormal abundance of Amphistegina lobifera Larsen specimens observed on the south and west of the study area is noteworthy. It shows variable distribution in the sampling locations according the direction and distance to the submarine spring water (Figure 2). The diatom analysis revealed that there is diverse and rich community of diatomes around and near this springs (Meriç et al., 2009b, 2015, 2016, 2018). Benthic foraminifer species feed on diatomes, suggesting that the abundance of diatomes may serve as an important food source for Amphistegina lobifera Larsen. An increase as observed in Elphidium crispum (Linné) and Ammonia compacta Hofker populations as Amphistegina lobifera Larsen populations decrease. The abundance of Coscinospira hemprichii Ehrenberg, Peneroplis planatus (Fichtel and Moll), Lobatula lobatula (Walker and Jacob), Cibicidella variabilis (d'Orbigny) individuals have with abnormal test morphologies, and observed in Spiroloculina angulosa Terquem individuals have a double apertures in the study is noteworthy (Yokeş et al., 2014).

Geochemical Characteristics of the Sediments and Peneroplis planatus (Fichtel and Moll) Tests from the Study Area.

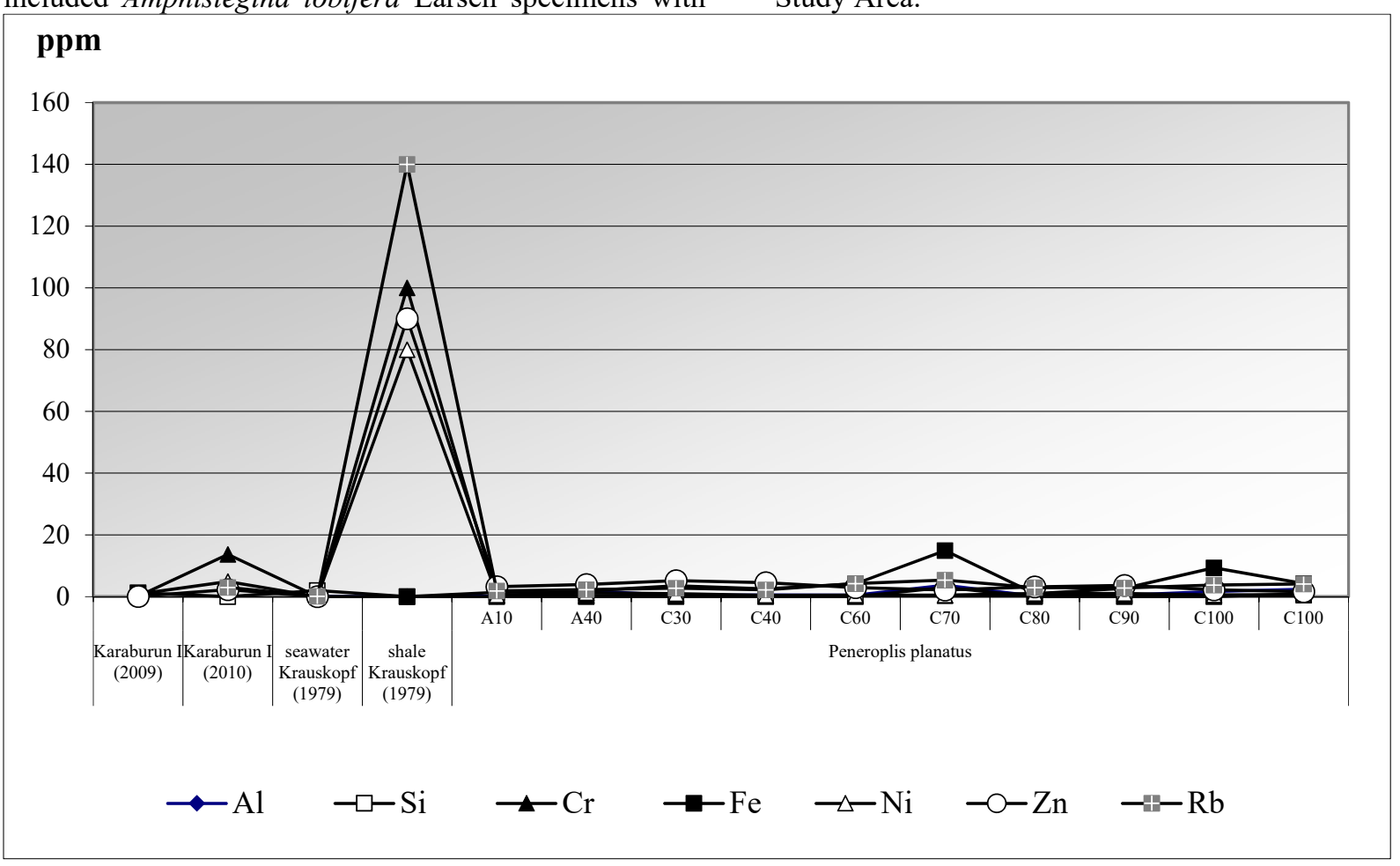

Figure 6. Distribution of heavy metal and trace elements in coloured tests of Peneroplis planatus in some samples and seawater in Karaburun, Krauskopf (1979) comparison with reference values for seawater and shale.

Heavy metal and trace element analysis of the colored Peneroplis planatus (Fichtel and Moll) samples from Çeşme-Ilıca Bay showed that Ti, Cr, Te and $\mathrm{Y}$ had the highest values in Station $\mathrm{A} 10 ; \mathrm{Na}, \mathrm{Al}, \mathrm{Si}, \mathrm{Fe}, \mathrm{Rb}$ and $\mathrm{Pa}$ in A30; Mo in A40; $\mathrm{Ni}$ and $\mathrm{Y}$ in B5; $\mathrm{Mg}$ and $\mathrm{Tc}$ in B20; $\mathrm{K}$ in $\mathrm{B} 30$; $\mathrm{Zn}$ and $\mathrm{Ru}$ in $\mathrm{C} 10$. The geochemical content of the tests were compared to the water sample from the
Çeşme-Ilıca Bay and it was found that $\mathrm{Ti}, \mathrm{Cr}$ and $\mathrm{Fe}$ were higher in tests. When the results were compared to Krauskopf (1979) seawater reference values, high values of $\mathrm{Mg}, \mathrm{Al}, \mathrm{Si}$, (in A30), Ti, Cr, Fe, Ni, Zn, Rb and Y attracts attention. $\mathrm{Al}, \mathrm{Si}, \mathrm{Fe}$ and $\mathrm{Mo}$ (A40) values were found to be higher compared to Krauskopf (1979) shale reference. Another interesting finding was the presence of 
$\mathrm{Pa}$ (A30), Mo (A40) and $\mathrm{Ru}(\mathrm{C} 10)$ in only one sediment sample (Bergin et al., 2006; Meriç et al., 2012a).

Microprobe analysis of normal specimens of Peneroplis planatus (Fichtel and Moll) tests from the Çeşme-Ilıca Bay (samples A10, A15, A30, A40, B5, B20, B30 and $\mathrm{C} 10)$ revealed that $\mathrm{Mg}, \mathrm{Si}, \mathrm{Fe}, \mathrm{Zn}, \mathrm{Rb}, \mathrm{Y}, \mathrm{Tc}$ and $\mathrm{Mo}$ concentrations content of the tests were not uniform in all samples (Figure 4). Mg and Tc had the highest values in $\mathrm{A} 5$ and B20, as Si, Fe and Rb in A30, Mo in A40. Of the elements with the lowest values, $\mathrm{Al}$ and $\mathrm{Si}$ were recorded in all tests except $\mathrm{A} 30$ and $\mathrm{K}$ was recorded in all tests except B30 (Meriç et al., 2012a, b, c). Microprobe analysis of Peneroplis planatus tests from Station I'in Karaburun (samples A10, A40, C30, C40, C60, C70, C80, $\mathrm{C} 90$ and $\mathrm{C} 100)$ showed that the elements with the highest values were $\mathrm{Ni}$ in $\mathrm{A} 40 ; \mathrm{Zn}$ in $\mathrm{C} 30 ; \mathrm{Zn}$ in $\mathrm{C} 70 ; \mathrm{Al}, \mathrm{Fe}$ and $\mathrm{Rb}$ in $\mathrm{C} 70$; $\mathrm{Cr}$ in $\mathrm{C} 90$ (Figure 5). Elements with lowest values were $\mathrm{Al}$ and $\mathrm{Rb}$ in $\mathrm{A} 10 ; \mathrm{Mn}$ and $\mathrm{Ni}$ in $\mathrm{C} 40, \mathrm{Fe}$ in $\mathrm{C} 80$; $\mathrm{Zn}$ in $\mathrm{C} 100$ (Meriç et al., $2012 \mathrm{~b}$ ). In general, $\mathrm{Zn}$ in $\mathrm{C} 30$; $\mathrm{Fe}$ in $\mathrm{C} 70$ and $\mathrm{C} 100$ were the highest values. When geochemical findings of test analysis compared with Karaburun water sample and Krauskopf (1979) seawater reference values, $\mathrm{Al}, \mathrm{Cr}, \mathrm{Fe}, \mathrm{Zn}$ and $\mathrm{Rb}$ were found to be higher. $\mathrm{Al}, \mathrm{Fe}$ and $\mathrm{Rb}$ were higher compared to the Krauskopf (1979) shale reference (Figure 6).

Amphistegina lobifera Larsen is abundantly found around the two submarine springs in the Gulf of Kuşadas1, which is located on the south of Ilica Bay. It is also recorded on the NW coasts of the Karaburun Peninsula which is north to the study area. However, Amphistegina lobifera Larsen is absent in the Ilica Bay, which constitutes the most important finding of this study. $\mathrm{Si}, \mathrm{Mg}$ and $\mathrm{Mo}$ concentrations were found to be high in the tests of some of the colored Peneroplis planatus (Fichtel and Moll) individuals. But, rare earth elements, such as, Tc, $\mathrm{Pa}, \mathrm{Ru}$ and Mo were observed in tests obtained from some sampling points.

\section{Discussion and Conclusion}

Along the Turkish Aegean coast, alien benthic foraminifer species have been observed around the submarine springs. However, abundance of individuals with colored tests, morphological deformities and togetherness, as well as the origin of alien species suggests the presence of special environmental as well as ecological conditions around the spring water, different from the other parts of Turkish coasts. Peneroplis arietinus, Cymbaloporetta plana and Amphisorus hemprichii are observed very abundant in the Gulf of Ilica and on SW coasts of Turkey. Sorites orbiculus also were observed commonly along the coast of SW Turkey.

The identified species are Nodopthalmidium antillarum (Cushman), Spiroloculina antillarum d'Orbigny, Triloculina fichteliana d'Orbigny, Euthymonacha polita (Chapman), Coscinospira acicularis (Batsch), Peneroplis arietinus (Batsch), Amphisorus hemprichii Ehrenberg, Sorites orbiculus Ehrenberg, Cymbaloporetta plana (Cushman). Besides, Peneroplis arietinus (Batsch), Spiroloculina antillarum d'Orbigny, Triloculina fichteliana d'Orbigny and Cymbaloporetta plana (Cushman), which have been previously recorded from southwestern Antalya were also recorded in the Ilıca Bay (Meriç et al,. 2012a).

The presence of hot water submarine spring water is a common characteristic of Kuşadası Pamucak Bay and Çeşme-Ilıca Bay. The Pacific and Red Sea originated alien benthic foraminifer species can reach these spots with various ways and not only survive around these springs, but also show south to north expansions (Meriç et al., 2010, 2011). In each three locations Peneroplid and Hauerinid individuals with colored tests were found. Peneroplid individuals with abnormal test morphology were also abundant in these locations. Pacific originated Euthymonacha polita (Chapman) has been first recorded in the Mediterranean Sea from Kuşadası-Pamucak Bay. On the northern and eastern parts of the Pamucak Bay the populations of alien species decreases and the assemblages of Ammonia compacta Cushman and Elphidium crispum (Linné) become dominant.

The abnormal togetherness of Vertebralina striata d'Orbigny and Coscinospira hemprichii Ehrenberg was also observed in Pamucak Bay. In previous studies togetherness of Peneroplis pertusus and P. planatus, Peneroplis planatus and Coscinospira hemprichii, Peneroplis pertusus and Coscinospira hemprichii have been observed (Meriç et al., 2008b, c, 2012c).

On the other hand, Amphistegina lobifera Larsen which was abundantly found in Kuşadası-Pamucak Bay (Figure 2) and on west coast of Karaburun Peninsula was not observed in other locations. In Pamucak Bay, 1954 individuals were recorded in 5 gr of sediment, whereas 92 individuals were found in the 46 sediment samples from northwest Karaburun Peninsula, only a single specimen was found in the 17 sediment samples from Dilek Peninsula and none was found in Ilica Bay.

Euthymonacha polita (Chapman) has been first recorded on Turkish coastline from Gulf of Kuşadası and it was abundantly observed in Ilica Bay. The finding of an established population of Coscinospira acicularis (Batsch), which is found in Gulf of Aqaba (Red Sea), constituted the first record of this species from the Aegean Sea, as well as from the Mediterranean (Meriç et al., 2008a). The abundance foraminifer specimens with colored tests and conjoined twins of Peneroplis planatus (Fichtel and Moll)- Peneroplis pertusus (Forskal), abnormal aperture morphology observed in some Vertebralina striata d'Orbigny individuals are also characteristics of the region.

Atlantic originated benthic foraminifer Iridia diaphana Heron-Allen and Earland, Red Sea / Pacific originated benthic species Nodopthalmidium antillarum (Cushman), Triloculina fichteliana d'Orbigny, Euthymonacha polita (Chapman), Peneroplis arietinus (Batsch), Sorites orbiculus Ehrenberg, $S$. variabilis Lacroix, Cymbaloporetta plana (Cushman) C. squammosa (d'Orbigny) and Amphistegina lobifera Larsen were found on the northwest coasts of Karaburun Peninsula. 
Amphistegina lobifera Larsen was the most abundant of all (Meriç et al., 2012b). Although a submarine spring was not located in the study area, the presence of many fault lines found in the vicinity suggests that there might be water exits on the sea floor.

A typical Mediterranean foraminifer fauna was observed around the investigated submarine spring. Ammonia compacta Hofker and Elphidium crispum (Linné) were found to be the highly dominating species on the eastern line. On the other hand, the observation of Indo-Pacific originated species Quinqueloculina sp. C, Triloculina sp. A, Euthymonacha polita (Chapman), Pyramidulina catesbyi (d'Orbigny), Brizalina simpsoni (Heron-Allen and Earland), Amphistegina lessonii d'Orbigny for the first time on the Turkish coastline is noteworthy. Amphistegina lessonii d'Orbigny was previously reported from northwest of Crete Island (Hollaus and Hottinger, 1997) and Andros Island in the Middle Aegean Sea (Triantaphyllou et al., 2005, 2012; Langer et al., 2012). Besides, Haddonia sp. and Cymbaloporetta plana (Cushman), which are abundant on the southwestern coast of Turkey, Iridia diaphana Heron-Allen and Earland which is recorded in Ayvalik (North Aegean), were represented in the sediment with few individuals. Nodopthalmidium antillarum (Cushman) which was known from Gulf of Iskenderun and Adelosina carinatastriata Wiesner which was rarely observed on the Aegean coasts were found to be abundant in the study area.

The chemical compositions show that these thermal springs have carbonated sulphated waters with high $\mathrm{Na}, \mathrm{K}$ and $\mathrm{Mg}$ concentrations and carbonate hardness exceeds $50 \%$. Alkaline elements $(\mathrm{Na}, \mathrm{K})$ have higher values compared to the alkaline earth elements $(\mathrm{Ca}, \mathrm{Mg}) . \mathrm{Na}, \mathrm{Ca}$ and $\mathrm{K}$ are the most abundant cations, where is the most abundant anions are $\mathrm{Cl}, \mathrm{HCO}_{3}$ and $\mathrm{SO}_{4}$, suggesting that the waters are coming through limestones. These thermal waters have radioactive characteristics. Total alpha and total beta $\mathrm{Rn}^{222}$ values are higher in Kemerli, Kuşadası Spring and Cumalı. Total alpha values are ranging between $0.50 \pm 5.07(6)-4.57 \pm 27.23$ (5) Bq/1, whereas total beta values are found to be $2.29 \pm 5.11$ (2)- $22.19 \pm 26.61$ (1) Bq/l (Yokeş et al., 2014).

As a result, the environmental conditions created by the submarine springs on the Eastern Aegean coasts affect the benthic foraminifers. Abundance of individuals with colored tests and Red Sea originated benthic species suggests the presence of environmental and ecological conditions special to the vicinity of the spring. Physical (temperature, salinity, $\mathrm{pH}$, depth of submarine spring water), properties of chemical concentrations and radioactivity levels of the submarine spring waters play a role in the formation of the foraminiferal assemblages.

\section{References}

Babin, C. (1980). Elements of Palaeontology. John Wiley and Sons, Chichester, 446 pp.

Barut, I.F., Erdoğan (Yüzbaşıŏlu) N., Başak, E. (2004). Hydrogeochemical evaluation of Western Anatolian mineralwaters. Environmental Geology, 45 (4), 494503.

Başkan, E., Canik, B. (1983). Türkiye sıcak ve mineralli sular haritas1, Ege Bölgesi. Maden Tetkik ve Arama Enstitüsü Yayınları, No.189, 80 (in Turkish).

Bergin, F., Küçüksezgin, F., Uluturhan, E., Barut, İ.F., Meriç, E., Avşar, N., Nazik, A. (2006). The response of benthic foraminifera and ostracoda to heavy metal pollution in Gulf of İzmir (Eastern Aegean Sea). Estuarine, Coastal and Shelf Science, 66, 368-386.

Bignot, G. (1985). Elements of micropaleontology. London: Graham and Trotman Ltd., 217.

Çağlar, K.O. (1946). Türkiye Maden Suları ve Kaplıcaları. Maden Tetkik ve Arama Enstitüsü Yayınlart, Seri B, 11, 791 (in Turkish)

Çakmakoğlu, A., Bilgin, Z.R. (2006). PreNeogenestratigraphy of the Karaburun Peninsula W of Izmir Turkey). Bulletin of the Mineral Research and Exploration, 132, 33-61.

Demir, V., Aslan Okudan, E., Zeki, S., Yılmaz, İN. Gazioğlu, C. (2016). Mapping of Posidonia oceanica (L.) Delile Meadows Using Geographic Information Systems: A case study in Ufakdere - Kaş (Mediterranean Sea), International Journal of Environment and Geoinformatics,3(3):92-97.

Duman, M., Eronat,A.H., İlhan, T., Talas, E. and Küçüksezgin, F., 2019. Mapping Posidonia Oceanica (Linnaeus) Meadows in the Eastern Aegean Sea Coastal Areas of Turkey: Evaluation of Habitat Maps Produced Using the Acoustic Ground-Discrimination Systems. International Journal of Environment and Geoinformatics, 6(1): 67-75

Elberling, B., Knudsen, K.L., Kristensen, P.H., Asmund, G. (2003). Applying foraminiferal stratigraphy as a biomarker for heavy metal contamination and mining impact in a fjord in west Greenland. Marine Environmental Research, 55, 235-256.

Gazioğlu, C. (2018). Biodiversity, Coastal Protection, Promotion and Applicability Investigation of the Ocean Health Index for Turkish Seas. International Journal of Environment and Geoinformatics 5(3), 353- 367.

Hollaus, S.S., Hottinger, L. (1997). Temperature dependance of endosymbiotic relationships? Evidence from the depth range of Mediterranean Amphistegina lessonii(Foraminiferida) truncated by the thermocline. Ecologae geologicae Helvetiae, 90, 591-597.

Krauskopf, K.B. (1979). Introduction to Geochemistry. 2.nd edition. McGraw-Hill, New York, 617.

Langer, M.R., Weinmann, A.E., Lötters, S., Rödder, D. (2012). "Strangers" In Paradise: Modeling the biogeographic range expansion of the Foraminifera Amphistegina in the Mediterranean Sea. Journal of Foraminiferal Research, 42 (3), 234-244.

Loeblich, A.R.Jr., Tappan, H. (1988). Foraminiferal genera and their classification. New York, Van Nostrand Reinhold Company, 2 vols. 1182 pp.

Mason, B., Moore, C.B. (1982). Principles of Geochemistry. 4th edition, New York, J. Wiley and Sons, $331 \mathrm{pp}$.

Meriç, E., Avşar, N., Barut, İ. F., Yokeş, B., Dinçer, F. (2009a). Doğu Ege Denizi Kıyı Alanlarındaki Termal Mineralli Su Kaynaklarının Bentik Foraminifer 
Topluluklarına Etkisi. İstanbul Yerbilimleri Dergisi, 22 (2), 163-174. (in Turkish with English abstract)

Meriç, E., Avşar, N., Barut, İ. F., Yokeş, M. B., Taş, S., Eryilmaz, M., Dinçer, F., Bircan, C. (2009b). Kuşadası (Aydın) deniz dibi mineralli su kaynağı çevresi bentik foraminifer topluluğu hakkında görüş ve yorumlar. 13. Sualtı Bilim ve Teknolojisi (SBT 2009) Bildiriler Kitabı, 80-92. Uluslararas1 Kibrıs Üniversitesi, Lefkoşa, K. Kıbrıs. (in Turkish with English abstract)

Meriç, E., Avşar, N., Bergin, F. (2002). Midilli Adası (Yunanistan-Kuzeydoğu Ege Denizi) bentik foraminifer faunası ve bu toplulukta gözlenen yerel değişimler. Ç.Ü. Yerbilimleri (Geosound), 40-41, 177193. (in Turkish with English abstract)

Meriç, E., Avşar, N., Bergin, F., Barut, I.F. (2003a). Edremit Körfezi (Kuzey Ege Denizi, Türkiye) çökellerindeki bentik foraminifer topluluğu ile ekolojik koşulların incelenmesi. Ç. Ü. Yerbilimleri (Geosound), 43, 169-182. (in Turkish with English abstract)

Meriç, E., Avşar, N., Bergin, F., Barut, I.F. (2003b). A note three abnormal samples of benthic foraminifers from the Dikili Bay (Turkey) in northeastern Aegean Sea: Peneroplis planatus (Fichtel and Moll), Rosalina sp. and Elphidium crispum (Linné). Bulletin of the Mineral Research and Exploration, 127, 1-14.

Meriç, E., Avşar, N., Mekik, F., Yokeş, B., Barut, İ.F., Dora, Ö., Suner, F., Yücesoy-Eryılmaz, F., Eryılmaz, M., Dinçer, F., Kam, E. (2009c). Alibey ve Maden Adaları (Ayvalık-Balıkesir) çevresi genç çökellerinde gözlenen bentik foraminifer kavkılarındaki anormal oluşumlar ve nedenleri. Türkiye Jeoloji Bülteni, 52 (1), 31-84. (in Turkish with English abstract)

Meriç, E., Avşar, N., Nazik, A., Yokeş, B., Barut, İ. F., Eryılmaz, M., Kam, E., Taşkın, H., Başsarı, A., Dinçer, F., Bircan, C., Kaygun, A. (2012a). Ilıca Koyu (Çeşme-İzmir) bentik foraminifer-ostrakod toplulukları ile Pasifik Okyanusu ve Kızıldeniz kökenli göçmen foraminiferler ve anormal bireyler. Bulletin of the Mineral Research and Exploration, 145, 62-78. (in Turkish with English abstract)

Meriç, E., Avşar, N., Nazik, A., Yokeş, B., Dora, Ö., Barut, İ. F., Eryılmaz, M., Dinçer, F., Kam, E., Aksu, A., Taşkın, H., Başsarı, A., Bircan, C., Kaygun, A. (2012b). Karaburun Yarımadası kuzey kıyılarında sediment jeokimyasının bentik foraminifer ve ostrakod toplulukları üzerindeki etkileri. Bulletin of the Mineral Research and Exploration, 145, 22-47. (in Turkish with English abstract)

Meriç, E., Avşar, N., Nazik, A., Yokeş, M.B., Barut, İ.F., Suner, F., Sarı, E., Eryılmaz, M., Yücesoy-Eryılmaz, F., Dora, Ö., Dinçer, F., Kam, E. (2017). A multidisiplinary overview of factors controlling on meiofauna assemblages around Maden and Alibey islands-Ayvalık (Balıkesir, Eastern Aegean Sea), Journal of African Earth Sciences, 129, 558-578.

Meriç, E., Avşar, N., Yokeş, M. B., Dinçer., F., Karhan, S. Ü., Kalkan, E., Demir, V. (2016). Benthic foraminiferal assemblages from the Eastern Levantine coast of Turkey. International Journal of Environment and Geoinformatics (IJEGEO) 3 (2). 38-44.
Meriç, E., Avşar, N., Yokeş, M. B., Yücesoy-Eryilmaz, F., Dinçer, F., Demir, V. (2008a). Sharm El Sheikh kıyıları güncel bentik foraminifer topluluğu (GD Sina Yarımadası, Kızıldeniz, Misır). 12. Sualtı Bilim ve Teknoloji Toplantısı (SBT 2008) Bildiriler Kitabl, 128-137. Ege Üniversitesi, İzmir. (in Turkish with English abstract)

Meriç, E., Görmüş, M., Avşar, N., Yokeş, M. B., Dinçer, F. (2008b). Twin, triplet and quadruplet teratogens in benthic foraminifera from Antalya. Micropaleontology, 54, 293-306.

Meriç, E., Yokeş, B., Avşar, N. (2011). A new guest in Ilıca Bay (Çeşme-İzmir-Turkey): Coscinospira acicularis. Journal of Marine Biological Association of the United Kingdom, 4, e94, 1-5.

Meriç, E., Yokeş, M. B., Avşar, N., Bircan, C. (2010). An oasis for alien benthic foraminifera in the Aegean Sea. Aquatic Invasions, 5 (2), 191-195.

Meriç, E., Yokeş, M. B., Avşar, N., Bircan, C. (2012c). A new observation on abnormal development in benthic foraminifers: Peneroplis pertusus (Forskål)Peneroplis planatus (Fichtel and Moll) togetherness. Anales de Biologia, 34, 41-46.

Meriç, E., Yokeş, M. B., Nielsen, J. K., Görmüş, M., Avşar, N., Dinçer, F. (2008c). Abnormal formations in Peneroplids: Peneroplis-Coscinospira togetherness. Anales de Biologia, 30, 1-7.

Meriç, E., Yokeş, M.B., Avşar, N., Dinçer, F., (2016). New Observations of Alien Foraminifera On The Turkish Coasts Of The Aegean Sea (2012-2015). International Journal of Environment and Geoinformatics 3(1), 44-47.

Meriç, E., Yokeş, M.B., Avşar, N., Dinçer, F., (2018). Did Spiroloculina antillarum, Articulina carinata, Coscinospira hemphrichii, Peneroplis pertusus, $\mathrm{P}$. planatus, Sorites orbiculus, Astacolus insolithus, Siphonina tubulosa, Amphistegina lessonii and A. Lobifera reach the Mediterranean via the Suez Canal?. International Journal of Environment and Geoinformatics 5(3):378-385.

Meriç, E., Yokeş, M.B., Avşar, N., Dinçer, F., (2015). New Observations of Alien Foraminifera on the Turkish Coasts of the Aegean Sea (2008-2011). International Journal of Environment and Geoinformatics 2(2), 77-87.

Nigam, R., Saraswat, R., Panchang, R. (2006). Application of foraminifers in ecotoxicology: retrospect, perspect and prospect. Environment International, 32, 273-283.

Okuş, E., Sur, HI, Yüksek, A., Yılmaz, IN, AslanYımaz, A., Karhan, SÜ, Öz, Mİ, Demirel, N, Taş, S, Altıok, H., Gazioğlu, C. (2004). Datça-Bozburun özel çevre koruma bölgesinin denizsel ve klyısal alanlarının biyolojik çeşitliliğinin tespiti projesi, Ankara: TC Çevre ve Orman Bakanlığı ÖÇKK Başkanlığı.

Okuş, E., Yüksek, A., Yokeş, B., Yılmaz, İ.N., Aslan, A., Karhan, S.Ü., Demirel, N., Demir, V., Zeki, S., Taş, S., Sur, H.İ., Altıok, H., Müftüoğlu, A.E. Balkıs, N., Aksu, A. Doğani E. and C Gazioğlu. (2006): Marine Biological Diversity Assessment of Gokova Special Environmental Protection Area, Türkiye'nin Klyı ve Deniz Alanlarl VI. Ulusal Konferansi: 7-11 Kasım 2006, Muğla Üniversitesi, Muğla (Ed: Özhan,E.). 
Okuş, E., Yüksek, A., Yokeş, B., Yılmaz, I.N., AslanYılmaz, A., Karhan, S.U., Demirel, N., Demir, V., Zeki, S., Tas, S., Sur, H.İ., Altık, H., Müftüoğlu, A.E., Balkıs, N., Aksu, A., Doğan, E., Gazioğlu C. (2006). Gökova Özel Çevre Koruma Bölgesinin Klyı ve Deniz Alanlarının Biyolojik Çeşitliliğinin Tespiti Projesi Final Raporu, T.C. Çevre ve Orman Bakanlığ1 Özel Çevre Koruma Kurumu Başkanlığ $)$ ISBN:9758273-91-4.

Okus, E., Zeki, S., Demir, V., Demirel, N., Yüksek, A., Yilmaz, I. N., Yilmaz, A. A., Karhan, S. Ü. A., Müftüoglu, E., Tural, U., Murat, E., Gazioglu, C. (2010). Anchor Damage on Posidonia oceanica (L.) Delile Beds in The Gokova Bay. Rapp. Comm. int. Mer Médit., 39,:606.

Triantaphyllou, M.V., Dimiza, M. D., Koukousioura, O., Hallock, P. (2012). Observations on the life cycle of the symbiont-bearing Foraminifer Amphistegina Lobifera Larsen, $\mathrm{n}$ Invasive species in coastal ecosystems of the Aegean Sea (Greece, E. Mediterranean). Journal of Foraminiferal Research, 42,143-150.

Triantaphyllou, M.V., Tsourou, T., Koukousioura, O., Dermitzakis, M.D. (2005). Foraminiferal and ostracod ecological patterns in coastal environments of SE
Andros Island (Middle Aegean Sea, Greece). Revue de Micropaléontologie, 48 (4), 279-302.

Turekian, K.K., Wedepohl, K.H. (1961). Distribution of the Elements in some major units of the Earth's crust. Geological Society of America Bulletin, 72, 175-192.

Simav, Ö., Şeker, D.Z., Tanık, A. Gazioğlu, C. (2015). Determining the endangered fields of Turkish coasts with coastal vulnerability index. Journal of Map, 153: 1- 8 .

Yalçın, H., Meriç, E., Avşar, N., Tetiker, S., Barut, I.F., Yılmaz, S.., Dinçer, F. (2008). Mineralogical and geochemical features of colored benthic foraminifers from Aegean and southwestern coasts of Turkey. Micropaleontology, 54 (3-4), 351-370.

Yenal, O., Kanan, E., Bilecen, L., Öz, G., Öz, Ü., Göksel, A., Alkan, H., Kutluat S., Yassa, K. (1974). Türkiye Maden Sulan, Ege Bölgesi. İ.Ü. Tıp Fak. Hidroklimatoloji Kürsüsü, 351 (in Turkish).

Yokeş, M.B., Meriç, E., Avşar, N., Barut, İ., Tas, S., Eryilmaz, M., Dinçer, F.,Bircan, C. (2014). Opinions and comments on the benthic foraminiferal assemblage observed around the mineral submarine spring in Kuşadası (Aydın, Turkey). Marine Biodiversity Records, Marine Biological Association of the United Kingdom, /2014; e103, 1-17.

\begin{abstract}
Appendix 1
Maden and Alibey islands- Ayvalık (Balıkesir, NE Aegean Sea):

Rhabdammina abyssorum Sars, Iridia diaphana Heron-Allen and Earland, Eggerelloides scabrus (Williamson), Textularia bocki Höglund, Vertebralina striata d'Orbigny, Nubecularia lucifuga Defrance, Adelosina cliarensis (Heron-Allen and Earland), A. duthiersi Schlumberger, A. mediterranensis (Le Calvez J. and Y.), A. partschi (d'Orbigny), A. pulchella d'Orbigny, Spiroloculina angulata d'Orbigny, $S$. angulosa Terquem, $S$. antillarum d'Orbigny, $S$. depressa d'Orbigny, S. excavata d'Orbigny, $S$. ornata d'Orbigny, Siphonaperta agglutinans (d'Orbigny), S. aspera (d'Orbigny), Cycloforina contorta (d'Orbigny), C. villafranca (Le Calvez J. and Y.), Lachlanella undulata (d'Orbigny), L. variolata (d'Orbigny), Massilina secans (d'Orbigny), Quinqueloculina berthelotiana d'Orbigny, $Q$. bidentata d'Orbigny, $Q$. disparilis d'Orbigny, $Q$. jugosa Cushman, $Q$. lamarckiana d'Orbigny, $Q$. laevigata d'Orbigny, $Q$. seminula (Linné), Miliolinella dilatata (d'Orbigny), M. labiosa (d'Orbigny), M. semicostata (Wiesner), M. subrotunda (Montagu), M. webbiana (d'Orbigny), Pseudotriloculina laevigata (d'Orbigny), P. oblonga (Montagu), P. rotunda (d'Orbigny), P. sidebottomi (Martinotti), Pyrgo anomala (Schlumberger), Triloculina marioni Schlumberger, T. plicata Turquem, T. schreiberiana d'Orbigny, Wellmanellinella striata (Sidebottom), Sigmoilinita costata (Schlumberger), Parrina bradyi (Millet), Coscinospira hemprichii Ehrenberg, Laevipeneroplis karreri (Wiesner), Peneroplis pertusus (Forskal), P. planatus (Fichtel and Moll), Sorites orbiculus Ehrenberg, Polymorphina sp. 1 and 3, Neoeponides bradyi (Le Calvez), Neoconorbina terquemi (Rzehak), Rosalina bradyi Cushman, $R$. globularis d'Orbigny, Conorbella imperatoria (d'Orbigny), Lobatula lobatula (Walker and Jacob), Planorbulina mediterranensis d'Orbigny, Cibicidella variabilis (d'Orbigny), Acervulina inhaerens Schultze, Sphaerogypsina globula (Reuss), Asterigerinata mamilla (Williamson), Amphistegina lobifera Larsen, Nonion depressulum (Walker and Jacob), Ammonia compacta Hofker, A. parkinsoniana (d'Orbigny), A. tepida Cushman, Challengerella bradyi Billman, Hottinger and Oesterle, Cribroelphidium poeyanum (d'Orbigny), Porosononion subgranosum (Egger), Elphidium aculeatum (d'Orbigny), E. advenum (Cushman), E. complanatum (d'Orbigny), E. crispum (Linné), E. depressulum Cushman, E. macellum (Fichtel and Moll) and Elphidium sp.
\end{abstract}

\title{
Appendix 2
}

Karaburun Peninsula:

Iridia diaphana Heron-Allen and Earland, Rhabdammina abyssorum Sars, Eggerelloides scabrus (Williamson), Textularia bocki Höglund, Vertebralina striata d'Orbigny, Wiesnerella auriculata (Egger), Nodopthalmidium antillarum (Cushman), Nubecularia lucifuga Defrance, Adelosina carinata-striata Wiesner, A. cliarensis (Heron-Allen and Earland), A. duthiersi Schlumberger, A. mediterranensis (Le Calvez J. and Y.), Spiroloculina angulosa Terquem, S. depressa d'Orbigny, S. excavata d'Orbigny, S. ornata d'Orbigny, Siphonaperta agglutinans (d'Orbigny), S. aspera (d'Orbigny), Cycloforina contorta (d'Orbigny), C. villafranca (Le Calvez J. and Y.), Lachlanella undulata (d'Orbigny), L. variolata (d'Orbigny), Massilina gualteriana (d'Orbigny), M. secans (d'Orbigny), Quinqueloculina berthelotiana d'Orbigny, $Q$. bidentata d'Orbigny, $Q$. disparilis d'Orbigny, $Q$. lamarckiana d'Orbigny, $Q$. seminula (Linné), Q. vulgaris d'Orbigny, Miliolinella elongata Kruit, M. semicostata (Wiesner), M. subrotunda (Montagu), M. webbiana (d'Orbigny), Pseudotriloculina laevigata (d'Orbigny), P. oblonga (Montagu), P. rotunda (d'Orbigny), P. sidebottomi (Martinotti), Pyrgo elongata (d'Orbigny), Triloculina cf. bermudezi Acosta, T. fichteliana d'Orbigny, T. marioni Schlumberger, T. plicata Terquem, T. scheriberiana d'Orbigny, Sigmoilinita costata (Schulmberger), S. edwardsi (Schlumberger), Articulina carinata Wiesner, Euthymonacha polita (Chapman), Laevipeneroplis karreri (Wiesner), Peneroplis arietinus (Batsch), P. pertusus (Forskal), P. planatus (Fichtel and Moll), Sorites orbiculus Ehrenberg, S. variabilis Lacroix, Polymorphina sp.3, Reussella spinulosa (Reuss), Eponides concameratus (Williamson), Neoeponides bradyi Le Calvez, Neoconorbina terquemi (Rzehak), Rosalina bradyi Cushman, $R$. obtusa d'Orbigny, Pararosalina ef. dimorphiformis McCulloch, Pararosalina sp., Conorbella imperatoria (d'Orbigny), Discorbinella bertheloti (d'Orbigny), Cibicides advenum (d'Orbigny), Lobatula lobatula (Walker and Jacob), Planorbulina mediterranensis 
d'Orbigny, Cibicidella variabilis (d'Orbigny), Cymbaloporetta plana (Cushman), C. squammosa (d'Orbigny), Sphaerogypsina globula (Reuss), Asterigerinata mamilla (Williamson), Amphistegina lobifera Larsen, Nonion depressulum (Walker and Jacob), Ammonia compacta Hofker, A. parkinsoniana (d'Orbigny), A. tepida Cushman, Challengerella bradyi Billman, Hottinger and Oesterle, Cribroelphidium poeyanum (d'Orbigny), Porosononion subgranosum (Egger), Elphidium aculeatum (d'Orbigny), E. advenum (Cushman), E. complanatum (d'Orbigny), E. crispum (Linné), E. depressulum (Cushman).

\section{Appendix 3}

Çeşme-Ilıca Bay:

These are Textularia bocki Höglund, Spirillina vivipara Ehrenberg, Vertebralina striata d'Orbigny, Nodopthalmidium antillarum (Cushman), Nubecularia lucifuga Defrance, Adelosina carinata-striata Wiesner, A. cliarensis (Heron-Allen and Earland), A. mediterranensis (Le Calvez J. and Y.), Spiroloculina angulosa Terquem, S. antillarum d'Orbigny, S. ornata d'Orbigny, Siphonaperta agglutinans (d'Orbigny), S. aspera (d'Orbigny), Cycloforina contorta (d'Orbigny), C. villafranca (Le Calvez J. and Y.), Lachlanella variolata (d'Orbigny), Massilina gualteriana (d'Orbigny), M. secans (d'Orbigny), Quinqueloculina berthelotiana d'Orbigny, $Q$. bidentata d'Orbigny, Q. jugosa Cushman, Q. laevigata d'Orbigny, Q. lamarckiana d'Orbigny, Q. seminula (Linné), Miliolinella elongata Kruit, M. labiosa (d'Orbigny), M. subrotunda (Montagu), M. webbiana (d'Orbigny), Pseudotriloculina laevigata (d'Orbigny), P. oblonga (Montagu), P. rotunda (d'Orbigny), P. sidebottomi (Martinotti), Triloculina bermudezi Acosta, T. fichteliana d'Orbigny, T. marioni Schlumberger, T. scheriberiana d'Orbigny, Sigmoilinita costata (Schlumberger), S. edwardsi (Schlumberger), Articulina carinata Wiesner, Parrina bradyi (Millet), Euthymonacha polita (Chapman), Coscinospira acicularis (Batsch), C. hemprichii Ehrenberg, Laevipeneroplis karreri (Wiesner), Peneroplis arietinus (Batsch), P. pertusus (Forskal), P. planatus (Fichtel and Moll), Amphisorus hemprichii Ehrenberg, Sorites orbiculus Ehrenberg, Polymorphina sp.3, Polymorphina sp.5, Polymorphina sp.7, Brizalina spatulata (Williamson), Reussella spinulosa (Reuss), Neoeponides bradyi Le Calvez, Gavelinopsis praegeri (HeronAllen and Earland), Neoconorbina terquemi (Rzehak), Rosalina bradyi Cushman, $R$. globularis d'Orbigny, Pararosalina cf. dimorphiformis McCulloch, Planoglabratella opercularis (d'Orbigny), Cyclocibicides vermiculatus (d'Orbigny), Lobatula lobatula (Walker ve Jacob), Planorbulina mediterranensis d'Orbigny, Cibicidella variabilis (d'Orbigny), Cymbaloporetta plana (Cushman), C. squammosa (d'Orbigny), Miniacina miniacea (Pallas), Asterigerinata mamilla (Williamson), Nonion depressulum (Walker and Jacob), Ammonia compacta Hofker, A. parkinsoniana (d'Orbigny), A. tepida Cushman, Challengerella bradyi Billman, Hottinger and Oesterle, Cribroelphidium poeyanum (d'Orbigny), Porosononion subgranosum (Egger), Elphidium aculeatum (d'Orbigny), E. advenum Cushman, E. complanatum (d'Orbigny), E. crispum (Linné) and E. depressulum (Cushman).

\section{Appendix 4}

Gulf of Kuşadası:

Lagenammina fusiformis (Williamson), Iridia diaphana Heron-Allen and Earland, Haddonia sp., Eggerelloides advenus (Cushman), E. scabrus (Williamson), Textularia bocki Höglund, T. truncata Höglund, Cornuspira foliacea Philippi, Vertebralina striata d'Orbigny, Nodopthalmidium antilarum (Cushman), Nubecularia lucifuga Defrance, Adelosina carinata-striata Wiesner, A. cliarensis (Heron-Allen and Earland), A. duthiersi Schlumberger, A. mediterranensis (le Calvez J. and Y.), A. partschi (d'Orbigny), A. pulchella d'Orbigny, Spiroloculina angulosa Terquem, S. depressa d'Orbigny, S. dilatata d'Orbigny, S. excavata d'Orbigny, S. ornata d'Orbigny, Siphonaperta agglutinans (d'Orbigny), S. aspera (d'Orbigny), S. dilatata (le Calvez J. and Y.), S. irregularis (d'Orbigny), Hauerina diversa Cushman, Cycloforina contorta (d'Orbigny), C. villafranca (le Calvez J. and Y.), Lachlanella undulata (d'Orbigny), Massilina gualteriana (d'Orbigny), M. secans (d'Orbigny), Quinqueloculina berthelotiana d'Orbigny, $Q$. bidentata d'Orbigny, $Q$. disparilis d'Orbigny, $Q$. jugosa Cushman, $Q$. laevigata d'Orbigny, $Q$. lamarckiana d'Orbigny, $Q$. limbata d'Orbigny, $Q$. seminula (Linné), Quinqueloculina sp. C, Miliolinella semicostata (Wiesner), M. subrotunda (Montagu), M. webbiana (d'Orbigny), Pseudotriloculuina laevigata (d'Orbigny), P. oblonga (Montagu), P. rotunda (d'Orbigny), Triloculina affinis d'Orbigny, T. bermudezi Acosta, T. marioni Schlumberger, T. plicata Terquem, T. schreiberiana d'Orbigny, T. tricarinata d'Orbigny, Triloculina sp. A, Sigmoilinita costata (Schlumberger), S. edwardsi (Schlumberger), Sigmoilopsis schlumbergeri (Silvestri), Parrina bradyi (Millet), Euthymonacha polita (Chapman), Laevipeneroplis karreri (Wiesner), Peneroplis pertusus (Forskal), P. planatus (Fichtel and Moll), Sorites orbiculus Ehrenberg, S. variabilis Lacroix, Laevidentalina inflexa (Reuss), Lenticulina cultrata (Montfort), Pyramidulina catesbyi (d'Orbigny), Polymorphina sp. 1, 2, 3, Brizalina simpsoni (Heron-Allen and Earland), B. spathulata (Williamson), Bulimina elongata d'Orbigny, Reussella spinulosa (Reuss), Fursenkoina acuta (d'Orbigny), Valvulineria bradyana (Fornasini), Eponides concameratus (Williamson), Neoeponides bradyi le Calvez, Gavelinopsis praegeri (Heron-Allen and Earland), Neoconorbina terquemi (Rzehak), Rosalina bradyi Cushman, R. floridensis (Cushman), R. globularis d'Orbigny, Conorbella imperatoria (d'Orbigny), Discorbinella bertheloti (d'Orbigny), Cibicides advenum (d'Orbigny), Lobatula lobatula (Walker and Jacob), Cyclocibicides vermiculatus (d'Orbigny), Planorbulina mediterranensis d'Orbigny, Cibicidella variabilis (d'Orbigny), Cymbaloporetta plana (Cushman), Sphaerogypsina globula (Reuss), Asterigerinata mamilla (Williamson), Amphistegina lessonii d'Orbigny, A. lobifera Larsen, Nonion depressulum (Walker and Jacob), Astrononion stelligerum (d'Orbigny), Ammonia compacta Hofker, A. parkinsoniana (d'Orbigny), A. tepida Cushman, Challengerella bradyi Billman, Hottinger and Oesterle, Cribroelphidium poeyanum (d'Orbigny), Porosononion subgranosum (Egger), Elpidium aculeatum (d'Orbigny), E. advenum (Cushman), E. complanatum (d'Orbigny), E. crispum (Linné), E. depressulum Cushman, E. macellum (Fichtel and Moll). 
Plate 1.

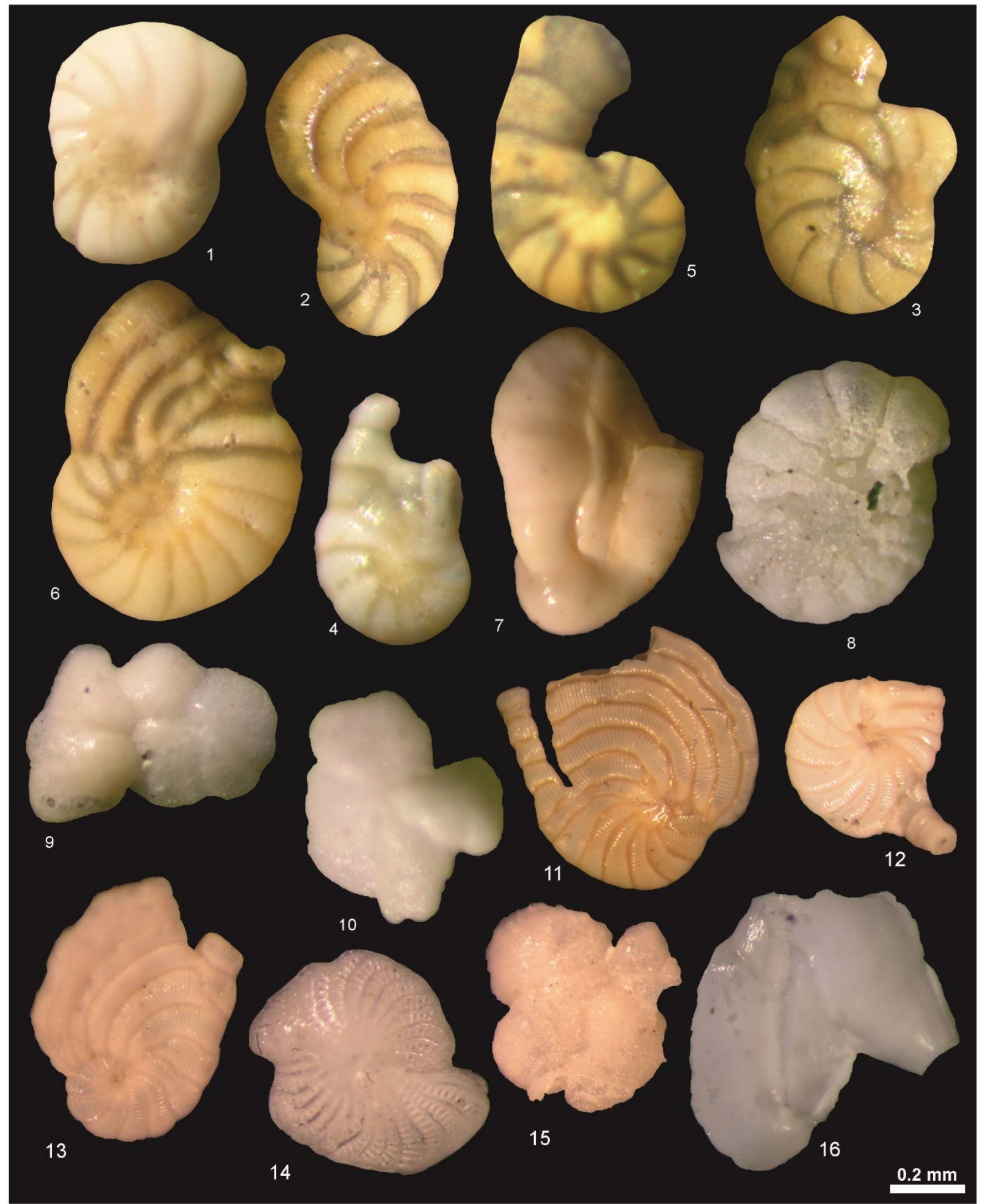




\section{Plate 2.}

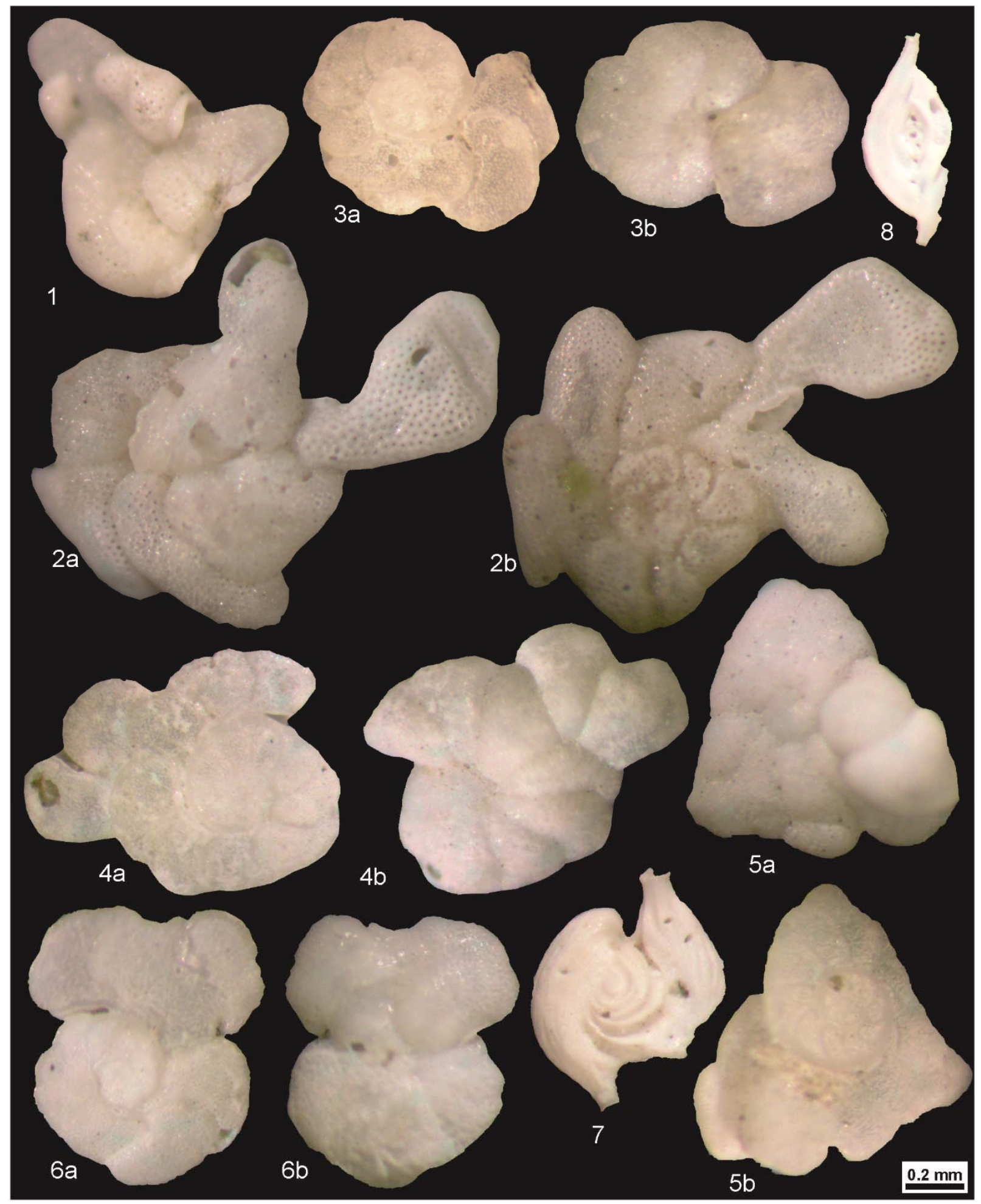




\section{Plate 3.}
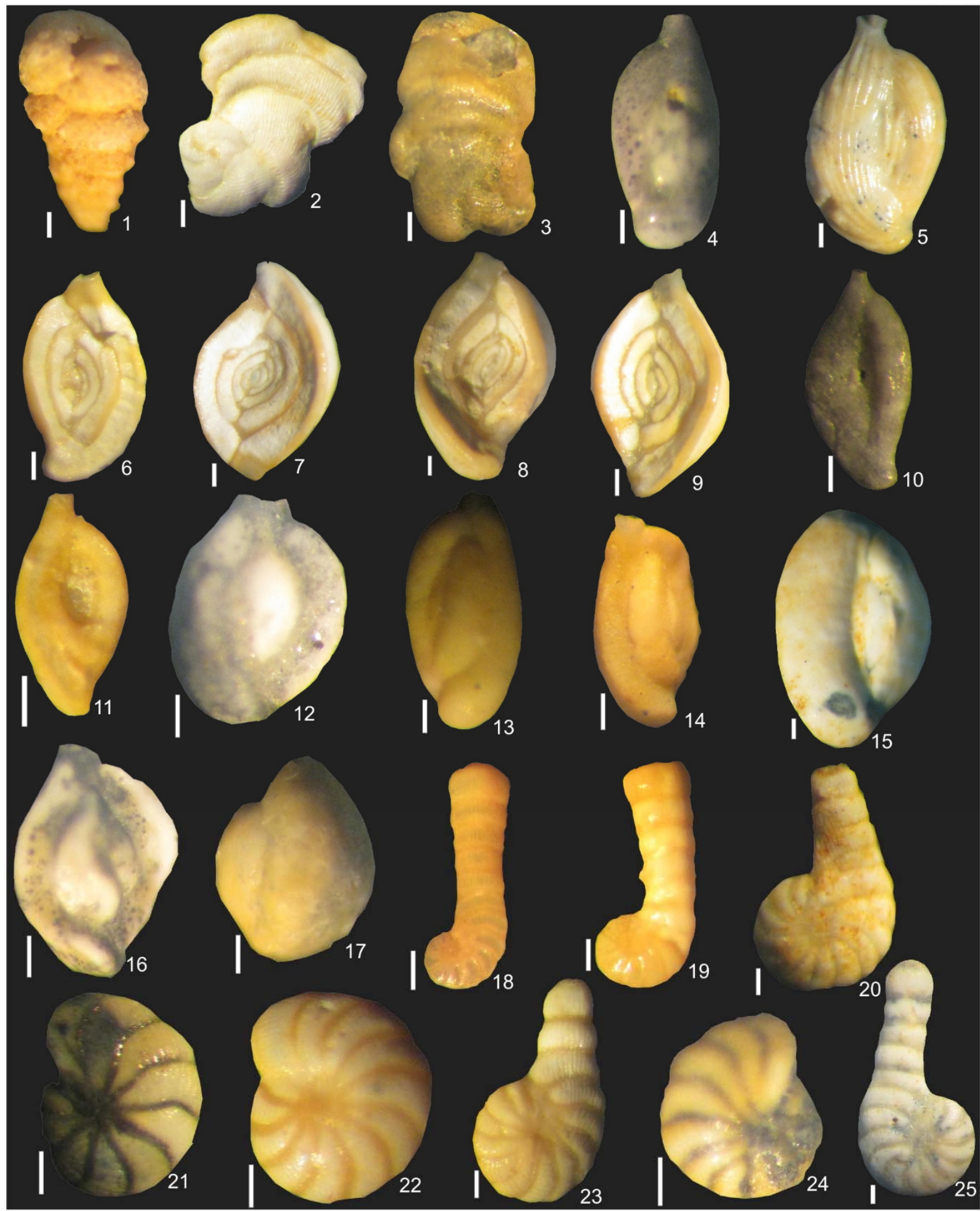


\section{Plate 4.}

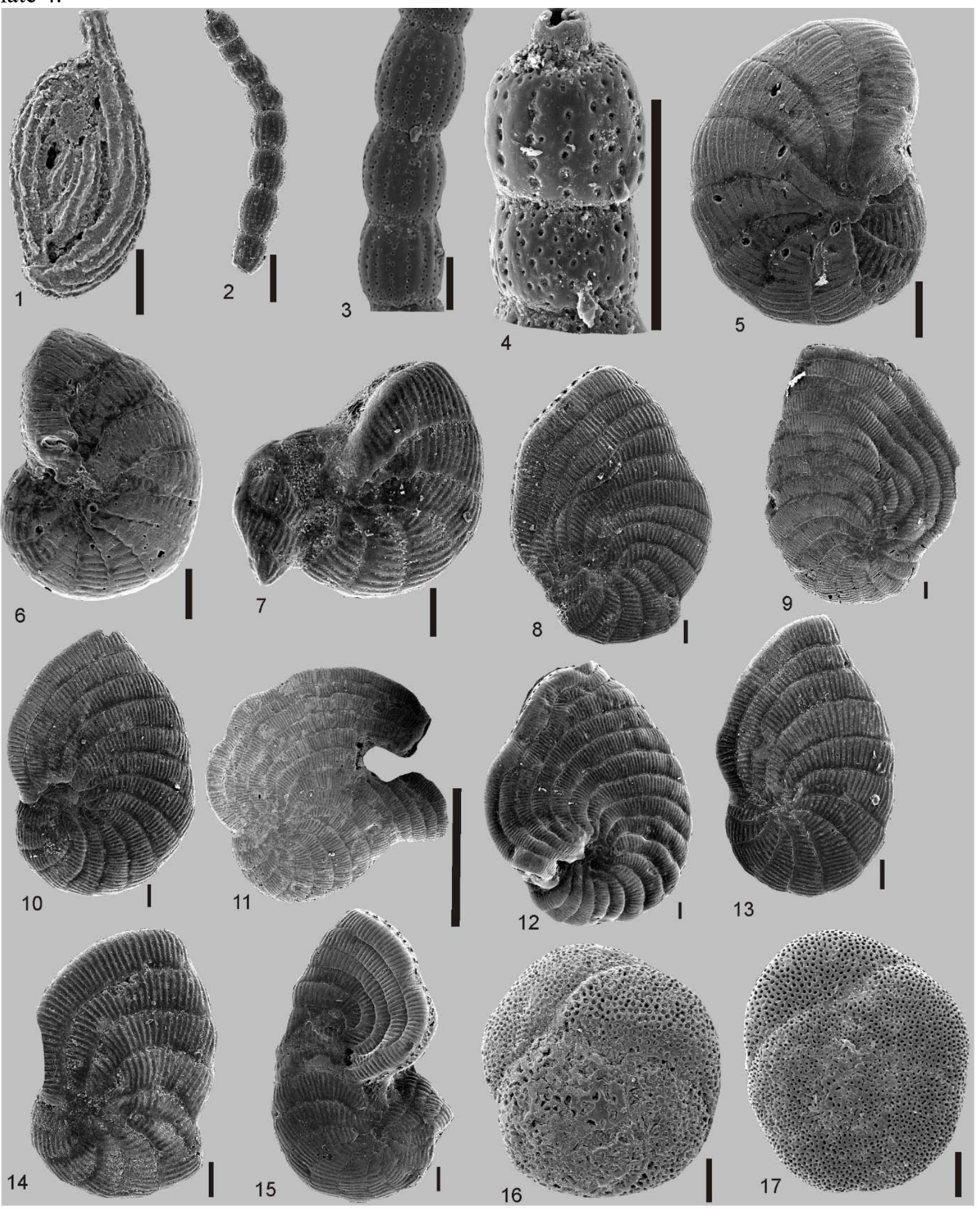

